\title{
Vendian foreland basin of the Siberian cratonic margin: Paleopangean accretionary phases
}

\author{
J. K. Sovetov \\ Institute of the Earth's Crust, Siberian Division, Russian Academy of Sciences
}

\begin{abstract}
Vendian, chiefly clastic sedimentation on the southwest of the Siberian craton is discussed under the tenet of a foreland basin that came into being in the Vendian epoch at the margin of the Siberian continent (craton) due to its collision with island arcs and microcontinents. The Vendian foreland basin of the Siberian cratonic margin, over $3000 \mathrm{~km}$ in length, was formed in the Early and Late Vendian. To use a paleotectonic framework, the terrestrial and marine deposition in point took place in the Yenisei-Baikal belt of foredeeps and in its coeval Baikit-Nepa belt of forebulges in the cratonic interior. Vendian age of molasse and the foreland basin is proved by new data: (1) tillites reported from the base of the Oselkovaya Group (Marnya Formation) of the Sayan foredeep and (2) the find of a Metazoa mollusk biota. The tillite-bearing horizon occurs at the base of the "lower marine assemblage" and, using cyclic sequences and carbonate sedimentary marker systems, it is traceable on the Yenisei Ridge, in Cisbaikalia, and in the cratonic interior. Sedimentologic data and the vector of clastic transport suggest that the ice cap was located on the Siberian craton, and the Siberian glacial horizon is correlatable to the global Laplandian horizon of the Vendian [Chumakov, 1978]. The foreland basin passed three evolutionary phases: (1) initial accretionary, (2) glacial (pre-collisional), and (3) collisional. Based on sedimentologic data, each phase falls into several evolutionary stages, each stage reflecting an erosion pulse and redeposition of clastic sediments. During the accretionary and collisional phases, changes in sedimentary systems were associated with tectonic activity and, indirectly, with eustatic sea-level oscillations. During the glacial phase, deposition of third-order cyclic sequences was chiefly controlled by eustatic changes of the sea-level, forced by growth and melting of ice caps. The synchroneity and interplay of climatic and tectonic events in the Vendian on most continents and microcontinents can be explained by a model for the Paleopangean supercontinent accretion in the Vendian.
\end{abstract}

\section{Introduction}

Two issues - the timing of orogeny in the Late NeoProterozoic at the margin of the Siberian craton and the type of basin that records this event-are interrelated while addressing global tectogenesis and accretion of the Vendian supercontinent. Previous notions on the age and tectonic

Copyright 2002 by the Russian Journal of Earth Sciences.

Paper number TJE02092.

ISSN: $1681-1208$ (online)

The online version of this paper was published 29 October 2002. URL: http://www.agu.org/wps/rjes/v04/tje02092/tje02092.htm (geodynamic) implications of Late Precambrian terrigenous piles along the southwestern margin of the Siberian craton were discussed in [Sovetov, 1977]. Posing the issue of Precambrian age for the Motskaya and Oselkovaya Groups in the Cis-Sayan region and in the Baikalian assemblage in Cisbaikalia became possible following the report on paleontologic evidence of Lower Cambrian age for their overlying and closely associated carbonate and, in the Irkutsk amphitheater, carbonate-halite-sulfate deposits [Lermontova, 1951]. At first, due to the lack of paleontologic data, the lower limit of the Cambrian was drawn along the sharp lithologic boundaries and unconformity surfaces at the base of the Kachergat-Ushakovka Group [Tetyaev, 1928], Ushakovka Formation [Obruchev, 1937; Pavlovsky, 1937], and Motskaya Formation [Mordovsky, 1958; Zharkov et al., 1974] 
and, based on correlation with the stratotypic section, inside the carbonate succession at the base of the Usolka Formation [Khomentovsky and Repina, 1965]. The latter position was approved officially in [Resolutions..., 1983] and, not so unanimously, in [Resolutions..., 1989].

Within Late Precambrian terrigenous successions of the southwestern Siberian craton, stratigraphic position of the Vendian, as the terminal system of the Proterozoic, was determined by correlating portions of these successions with the Yudoma assemblage (Group), the acknowledged counterpart of the Vendian System on the southeast of the study region [Khomentovsky, 1985; Khomentovsky et al., 1972; Sokolov, 1997]. The lithologic approach to correlation, supported by the notions on "sharp" geologic boundaries and by disputed data on phytoliths, was used to draw the lower boundary of stratigraphic counterparts of the $\mathrm{Yu}$ doma Group in southwestern regions of the Siberian craton at the base of the Ushakovka and Motskaya Groups and their correlative Formations [Khomentovsky, 1985, Shenfil, 1991). Using this correlation grid, only the uppermost Formations, crowning thick terrigenous Groups-Nemchansky (Chapa), Taseyeva, Oselkovaya, and Uluntui-KachergatUshakovka-were ascribed to the Vendian, whereas the greater portion of these units was dated to the Riphean and attributed to the Upper Baikalian. Based on petrographic composition of sandstones, I have demonstrated a stratigraphic correspondence to exist between the greater, upper part of Late Precambrian clastic successions on the Yenisei Ridge, in the Cis-Sayan region, and in Cisbaikalia, within the span of the Aisa and Yenisei-Sayan horizons, and the basal terrigenous sequence of the cratonic cover [Sovetov, 1977], or the lower part of the Yudoma Group. This study offers new data on Vendian age for the clastic molasse successions just mentioned, which fill in foredeeps on the southwest of the Siberian craton.

The tenet of the Early Cambrian (in this study, Vendian) orogeny and related molasse deposition on the southwestern margin of the Siberian craton was proposed as early as the first half of the 20th century [Obruchev, 1927; Shatsky, 1932] and refined in [Grigoriev and Semikhatov, 1961; Predtechensky, 1960; Semikhatov, 1962; Zaitsev, 1954]. In this region, tectonic entities associated with orogeny have been termed variously as "miogeosyncline" [Khomentovsky, 1959; Semikhatov, 1962], "marginal basin" [Khain et al., 1967; Khomentovsky, 1945; Krasilnikov, 1963; Yanshin, 1962; Zamaraev, 1967], or "a system of cratonic margin basins, genetic counterparts to marginal basins in Phanerozoic fold systems" [Postelnikov, 1973]. The opinions regarding the types of Late Precambrian tectonic entities differ widely, depending on which stratigraphic unconformity was given a leading role-i.e., on how the basins were delimited from below and which lithologic assemblages were specified as filling the basins. My own sedimentologic study on Late Riphean to Vendian successions on the Yenisei Ridge has convinced me that one should discriminate between (a) the evolutionary phase of the Late Riphean aulacogen with its respective basins on the Siberian craton and (b) the Vendian collisional phase, involving the formation of foredeeps and molasse [Sovetov, 1977, 1993, 1996; Sovetov et al., 1995].

This paper is intended to show that (1) the Late Precam- brian terrigenous assemblage on the southwestern Siberian craton has Vendian age and is the fill of a marginal foreland basin, (2) depositional stages were synchronous in all the foredeeps of the Siberian craton and depended on collision rates and global eustatic changes of the sea level, and (3) the principal evolutionary phases of the foredeeps and foreland basins of the Siberian craton are correlative to similar events on the other continents.

\section{Foreland Basins: A Response of Continental Lithosphere to Outer Impacts}

General consensus has it that foreland basins are formed through isostatic adjustment of the lithosphere to tectonic load in convergent geodynamic environments [Allen et al., 1986; Beaumont, 1981; Homewood et al., 1986; Ingersoll and Busby, 1995; Johnson and Beaumont, 1995; Jordan, 1981; Jordan et al., 1988; Miall, 1995; Stockmall et al., 1992]. Most typically, the foreland is the edge of the craton or continent, but, generally, it is a stable plate area, toward which the rocks of the belt were thrust or overfolded. Two principal classes of foreland basins - backarc and marginal-are recognized [Dickinson, 1974; Ingersoll and Busby, 1995; Miall, 1995]. The former originate in the backarc of continentalmargin volcanic arcs and are related to B-subduction and rifting of the overriding continental plate, whereas marginal foreland basins, irrespective of the collision type (arc-arc, arc-continent, continent-continent), arise on the downgoing plate - i.e., they are associated with the load of the orogen forming on the plate edge [Miall, 1995]. Typical examples of marginal foreland basins are seen in those of the Appalachians, Swiss Alps, and Himalayas. According to [Jordan et al., 1988], one should discern three levels of plate interaction, each contributing to the type and peculiarities of the marginal basin: (1) tectonic control of a regional or continental scale, (2) control imposed by the geometry of plate boundaries and variations of load and dynamics, bearing on the subsidence rate and large-scale architecture of sedimentary piles along the strike of the basin, and (3) response of the basin to local thrust movements. The main underlying cause of the formation of foreland basins is plastic or viscoplastic flexural bend of the lithosphere. In particular, in Alpine basins principal structural peculiarities are expressed in (1) the formation of foredeeps, their accompanying intramontane basins on the surface of thrust sheets (piggy-back basins), and foreland uplifts in the cratonic interior (forebulges), (2) the migration of depocenters, (3) the subsidence rate being different from that in basins on rift-related or passive margins, and (4) intraformational unconformities related to tectonic activity at basin margins [Allen et al., 1986]. The character and thickness of sediments are also influenced by orogen-transverse faults and strike slips.

Evidence critical to elucidating sediment sources and successive surfacing, in the evolving fold-and-thrust belt, of ever new rock assemblages, is provided by the study of petrofacies of the clastic material [Sovetov, 1977]. According to [Schwab, 1981], foreland basins of different ages exhibit the 
same regularity: The lower horizons of sedimentary piles are dominated by mature, craton-derived quartz material, while the upper molasse portions show an overwhelming predominance of rock clasts derived from passive margins, with fragments shed from volcanic arcs and suprasubduction assemblages being extremely rare. Similar conclusions were made by [Sovetov, 1977]. However, the Vendian foreland basin of the Siberian cratonic margin, with its extremely long heterogeneous marginal portion, displays exceptions to this rule.

Foreland basins pass a certain depositional evolution, from deep water environments with flysch deposition to shallow water and terrestrial environments typical of molasse deposition [Allen et al., 1986; Homewood et al., 1986; Ingersoll and Busby, 1995; Miall, 1995; Stockmall et al., 1992]. Flysch is deposited due to material being supplied both from the orogen and from the passive margin, which suffers, during collision, not only ductile but also brittle deformation. Depositional area existing during the initial phase of collision, with thick turbidite successions and olistostromes (wild flysch), is called "residual oceanic basin," which passes, not only in terms of evolution, but also laterally [Einsele, 1992], into the marginal foreland basin proper, with molasse deposition. A certain terminology mismatch arises when a "molasse basin" is reported to pond deep-water turbidites-i.e., flysch [Homewood et al., 1986]. I, for the sake of definiteness, discriminate between these two concepts, especially in view of my own observations showing that over most part of the Vendian marginal foreland basin, only shallow marine and terrestrial deposits were laid down.

\section{Vendian Paleotectonic Setup on the Southwest of the Siberian Craton}

My own notions on the paleotectonic features of the southwestern Siberian craton in the Vendian are depicted in Figure 1 [Sovetov, 2001b]. This sketch summarizes data on the spread and thickness of the Vendian molasse, on correlation of Late Precambrian between terrigenous assemblages of foredeeps and forebulges, on petrographic composition of psammites and paleotransport directions of clastic material in the upper fluvial assemblage, and on remnant turbidite (flysch) basins associated with the Vendian orogeny [Sovetov, 1977, 2001b; Sovetov and Blagovidov, 1998]. The outermost paleotectonic belt, also known as the outer belt of the Sayan-Altai fold region [Khomentovsky et al., 1978], includes the Cis-Sayan and Transbaikalian zones of accreted terranes and remnant basins; the belt of paratectonic uplifts incorporates the Cis-Sayan and, partly, Baikal-Patom zones; the belt of foredeeps is divided in two branchesYenisei and Baikal zones; and the belt of forebulges includes the Baikit-Nepa zone and its southern junction, the middle Angara zone.

That the Vendian paleotectonic zonation on the southern margin of the Siberian craton is consistent with the classic (Alpine) collision, is supported by remnant basins with graywacke turbidites (flysch) surviving west of marginal basement highs (Figure 2). The Mana tectonic zone ("basin") exhibits overthrusts and thrust sheets synchronous to the Vendian (Zhistyk-Anastasinsky) flysch basin. I adopt the nomenclature for regional stratigraphic units from [Khomentovsky et al., 1978]. Here, over a stretch of $14 \mathrm{~km}$ from Mt. Grebeshkov to Bespalsky Cliff, one finds lithotectonic assemblages that include (1) thrust sheets composed of the Riphean carbonate Angaloi Formation of shallow marine origin and thrust sheets made up of oceanic crustal rocks (the diabase-spilite Kuvai Formation), (2) lenses and veneers of tectonic breccias (a volcanomictic-carbonate melange up to 100-150 m thick) that underlie the thrust sheets and major recumbent folds in carbonate rocks, produced through overthrusting, (3) coarse clastics deposited by terrestrial and submarine gravitational flows from the material of disintegrated tectonic slices, (4) a terrigenous and carbonateterrigenous turbidite (flysch) basin incorporating deposits of submarine canyons with debrite packages and deep water fan lobes. The leading edge of the thrust sheets, as inferred from hinges of major recumbent folds tens to a few hundred meters in magnitude, trends roughly EW, and thrusting was directed, in the modern reference frame, from north to south, aslant to the cratonic edge. Deposits syngenetic to overthrusts make up a major olistostrome (wild flysch) assemblage composed of pebbles and blocks of the Angaloi Formation dolomites and Kuvai Group effusives and subvolcanic bodies, overridden by thrust sheets composed of these Groups. The remnant flysch basin of the Mana zone dates the onset of A-subduction and orogeny, in all likelihood, to the Early Vendian. Clastic deep-water sediments of the marginal basin must have originally been underlain by ocean floor basalts and distal carbonate sediments, supplied from the passive margin of the Siberian craton. Carbonate shelf deposits of the passive margin (Angaloi Formation) were detached and now occur in allochthonous position. The outer foreland to the fold-and-thrust belt of the Mana zone was provided by the Arzybei block with continental crust, on which molasse was deposited in synchroneity to the Zhistyk-Anastasinsky flysch basin [Khomentovsky et al., 1978]. Remnant basins of Vendian age have also been reported from western Transbaikalia and from the Patom margin of the Siberian craton [Mitrofanov and Mitrofanov, 2001], and they jointly make up a belt separated from the foreland basin by a chain of uplifts.

The Cis-Sayan zone of forebulges, as part of the Vendian structural setup of the craton, was identified indirectly, based on two facts: (1) massive transfer of clastic material from an outer source onto the craton and (2) the psammite composition. The measured flow directions of streams that gave rise to the upper terrestrial assemblage of the Chapa, Taseyeva, Oselkovaya, and Motsky Groups, clustering in $\mathrm{N}, \mathrm{NE}$, and $\mathrm{E}$ quarters, point clearly to clastic material being supplied from uplifts to the west of the craton, to be distributed along the foredeeps. Composition of clastic material from the upper terrestrial molasse assemblage was detailed in [Sovetov, 1977] and is depicted in Figure 3. The complete vertical petrographic succession is comprised of three petrographically distinct horizons, $\mathrm{QR}_{1}$, $\mathrm{QR}_{2}$, and $\mathrm{QF}$. This succession of petrographic horizons, as per the geodynamic classification of [Dickinson, 1988], may 


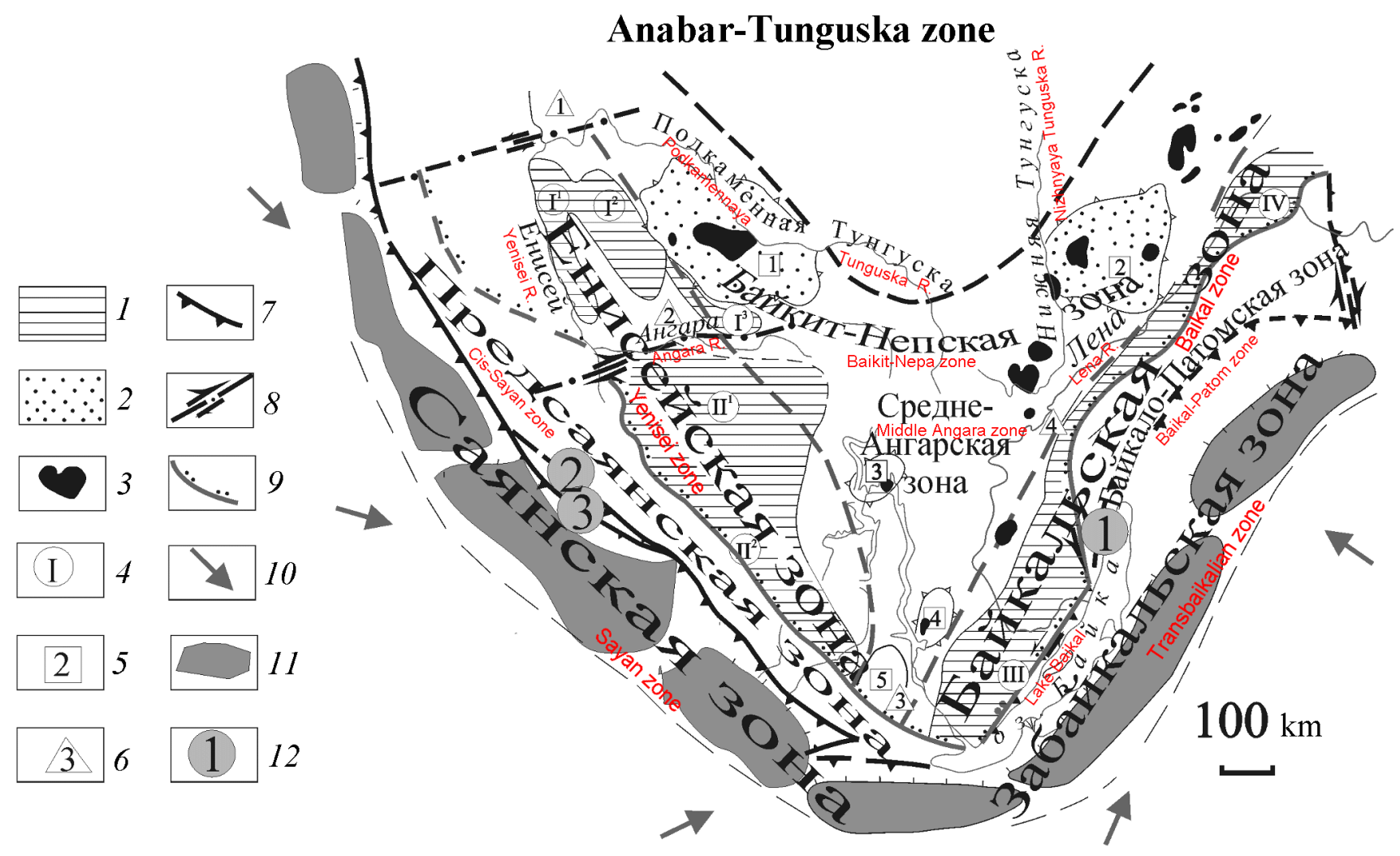

Figure 1. Paleotectonic sketch showing the southwestern Siberian craton (Late Vendian), modified after [Sovetov, 1977] and other sources.

1 - belt of foredeeps (Yenisei zone): I - Northern Yenisei (circled): $\mathrm{I}^{1}$ - Western, $\mathrm{I}^{2}$ - Eastern, $\mathrm{I}^{3}$ - Terya; II - Southern Yenisei-Cis-Sayan: II ${ }^{1}$ - Southern Yenisei, II ${ }^{2}$ - Cis-Sayan; Baikal zone: III - Cisbaikalian; IY - Nyuya-Dzherba; 2 - region of forebulges (compensatory uplifts) and isostatic uplifts (arches), Anabar-Tunguska zone; Baikit-Nepa zone (squared): 1 - Baikit, 2 - Nepa; Middle Angara zone: 3 - Bratsk, 4 - Atovsky, 5 - Belsky; 3 - major oil and gas fields; 4 - local basins and foredeeps; 5 - local arches of forebulges; 6 - internal uplifts separating foredeeps (in triangles): 1 - Podkamennaya Tunguska, 2 - Udoronga, 3 - Kitoi, 4 - Northern Baikal; 7 - outer boundary (structural suture) of the Siberian craton, separating the belt of accreted terranes from the belt of cratonic margin uplifts (CisSayan and Baikal-Patom zones); 8 - Mesozoic strike-slip faults; 9 - present-day boundary of cratonic cover; 10 - inferred direction of collision; 11 - belt of accreted terranes (Sayan and Transbaikalian zones); 12 - localities of radiometric dating of syncollisional metamorphism (1 - enderbites of the Nyurundikan assemblage [Amelin et al., 2000], 2 - hornblende-biotite plagiogneisses of the Shumikha assemblage and plagiogneisses (metadacites) of the Kansky greenstone belt [Rumyantsev et al., 2000] and trondhjemites of the Verkhnekansky Massif of the Kansky greenstone belt [Nozhkin et al., 2001].

record a change in the source type from a recycled orogen province to uplifted basement blocks. Typically, the province of recycled orogens is composed of highly mature metasedimentary successions of a passive continental margin, with metamorphic basement blocks supplying quartzfeldspathic (arkosic) material. By now, orthoquartzite and low feldspathic-quartz, weakly metamorphosed clay-silt and chert assemblages have been eroded, whereas in the Vendian they composed a so-called "paratectonic orogen" [Dewey and Bird, 1970]. The evolution of psammite composition from low feldspathic lithoclastic-quartz assemblages to quartzfeldspathic (arkosic) ones implies that the belt of forebulges contained concealed cratonic basement blocks. In all likelihood, not only was this belt an erosion region, but it also provided an intermediate reservoir for clastic material, in the form of small intramontane basins.

The belt of foredeeps and its contiguous, on the cratonic side, belt of forebulges, were delineated based on the greatest thickness of deposits of the Nemchansky, Taseyeva, and Oselkovaya Groups along the southwestern margin of the Siberian craton and on the sharp reduction of the thickness of these Groups or their stratigraphic correlatives in interior regions [Semikhatov, 1962; Semikhatov and Trapeznikov, 1965; Sovetov, 1977; Zamaraev, 1967]. The foredeep belt conforms to the bend of the cratonic edge and is comprised of individual basins in the Yenisei and Baikalian zones. In the western Yenisei foredeep, the "upper fluvial assemblage" of the Nemchansky (Chapa) molasse, as thick as $2 \mathrm{~km}$, has 

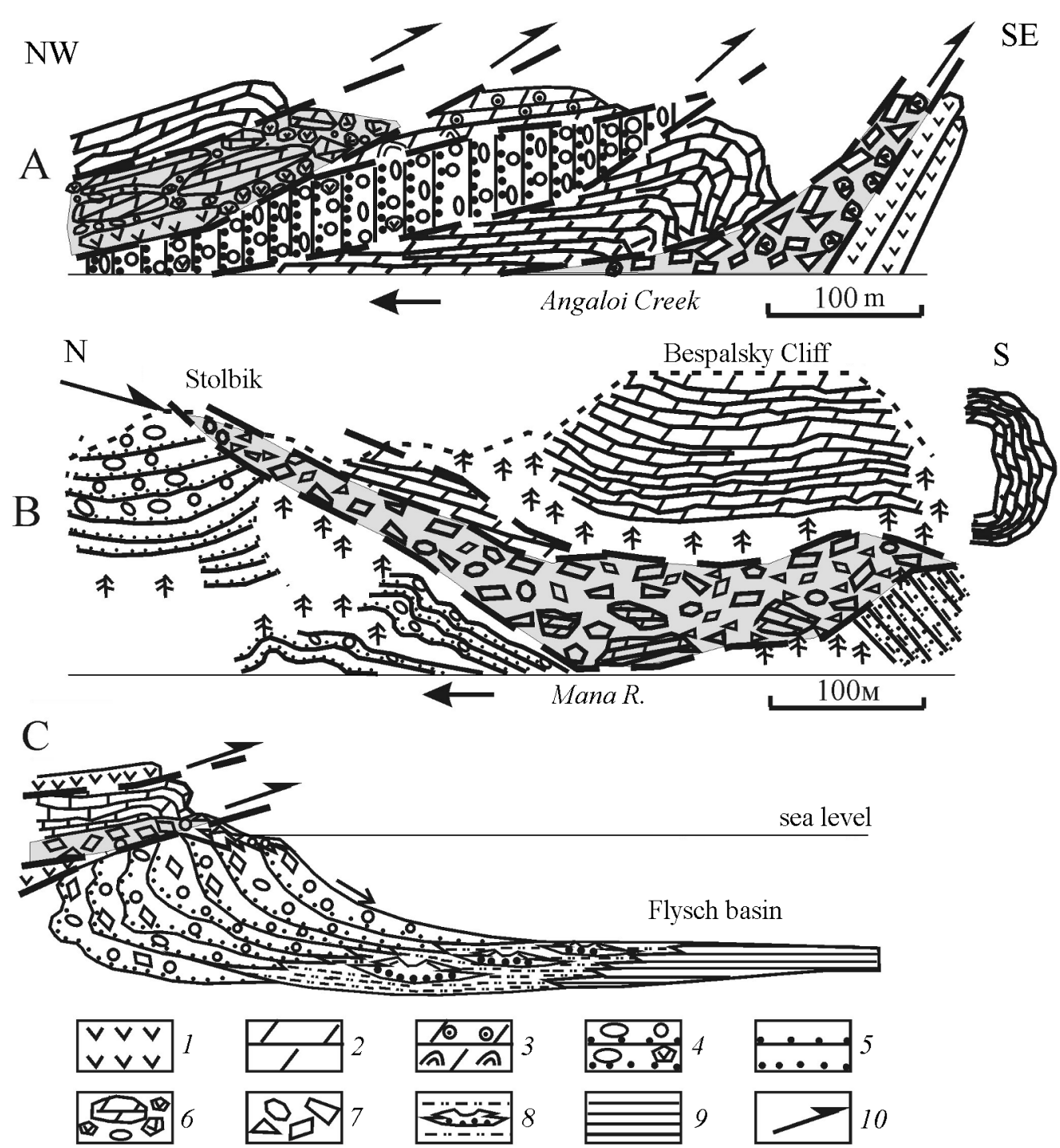

Figure 2. Vendian remnant basin in the Sayan belt of accreted terranes and basins (Mana zone). (A) Vendian fold-and-thrust pile (near the mouth of the Angaloi Creek). Thrust sheets are made up of oceanic crustal fragments (Kuvai volcanic suite), shelf carbonate deposits of the cratonic margin (Angaloi Formation), and a deformed remnant flysch basin. Thrust sheets are separated by zones of volcanomictic carbonate melange. (B) Same, at the Bespalsky Utes (Bespalsky Cliff)-Stolbik locality. Right, transverse section across a recumbent fold composed of the upper thrust sheet of Angaloi dolomites. Composition and shape of carbonate clasts are the same in tectonic melange and in gravitational flow deposits in the remnant flysch basin, deformed during accretion of island arc onto the craton in the Vendian. (C) A model for remnant flysch basin during the Early Vendian accretion of the Siberian craton. Zone of olistostrome and coarse debrite ("wild flysch") was related to syndepositional overthrusts. Slope deposits give way to medial flysch with submarine streams and the fan of graywacke turbidites (distal thin-bedded flysch) fringing it.

Symbols: 1 - basic effusives, Kuvai Group, 2 - dolomites, Angaloi Formation, 3 - same, preserving microphytolith and stromatolite structures, 4 - coarse-grained debrites with blocks and boulders of Kuvai and Angaloi rocks, 5 - thick-bedded sand debrites and turbidites lacking large fragments, 6 - tectonic melange of volcanomictic-carbonate composition, 7 - same, of carbonate composition, 8 - submarine streams and turbidites of fans and levees, 9 - thin-bedded turbidites: siliciclastic, carbonate, and hybrid, 10 - sense of overthrusting. 


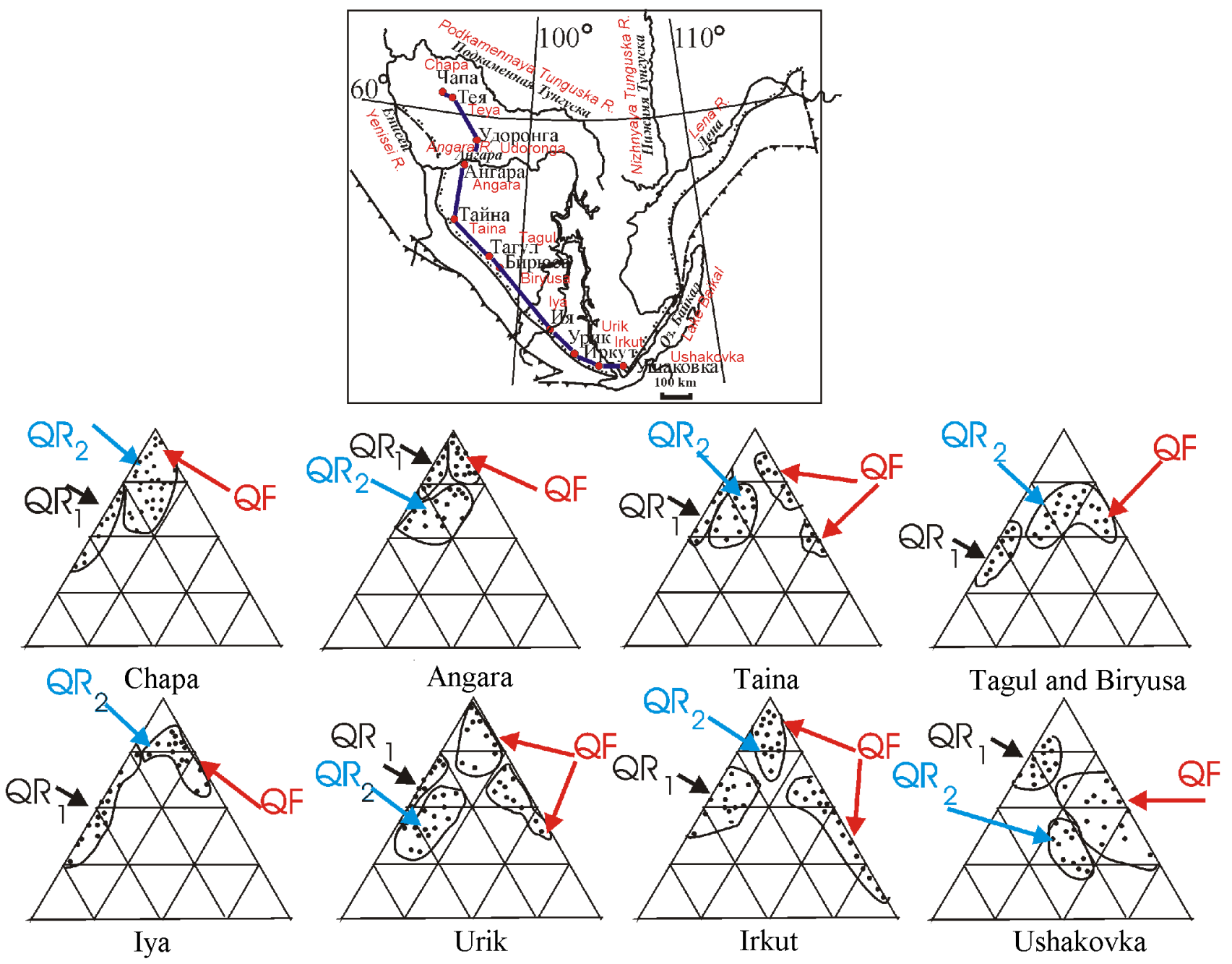

Figure 3. Composition of sandstones of the upper terrestrial assemblage of the Vendian molasse, after [Sovetov, 1977]. Three petrographic horizons: lower $-\mathrm{QR}_{1}$, middle $-\mathrm{QR}_{2}$, and upper $-\mathrm{QF}$, plotting on the QmFLt diagram [Dickinson, 1988] close to (1) the province of recycled orogens, (2) a mixed source of clastic material, and (3) the province of continental blocks on stable cratons and the province of uplifted basement blocks, respectively.

a northerly progradation direction, while the eastern Yenisei foredeep is featured by molasse deposits being as thick as $3.5 \mathrm{~km}$ and by an intricate easterly pattern of stream directions. The northern Yenisei foredeep is bounded on the cratonic side by the Baikit forebulge, where the thickness of strata synchronous to the Chapa (Nemchansky) Group ranges from a few hundred to tens of meters and, ultimately, to zero in the crestal portion [Sovetov et al., 1996]. On the east, the southern Yenisei-Cis-Sayan foredeep is bounded by the Baikit (Figure 4) and middle Angara forebulges, the latter stretching southward to separate the Yenisei and Baikal zones of foredeeps. The southern Yenisei-Cis-Sayan foredeep is likely to be comprised of two independent basins that are separated by an unclear structural boundary, but are marked by distinctive lithostratigraphic units - the Taseyeva and Oselkovaya Groups, both being as thick as $2 \mathrm{~km}$ (Figure 5). Syndepositional nature of the structural grain is apparent not only from thickness variations of deposits on the Belsky uplift in-between, but also from stratigraphic nomenclatures of the mappable sequences, dissimilar in the Cis-Sayan and Cisbaikalian foredeeps. In the Cisbaikalian foredeep, we identify stratigraphic correlatives of the Vendian terrigenous assemblage of the Yenisei zone in the sedimentary assemblage comprised of four Formations-Uluntui, Kachergat, Ushakovka, and Kurtun [Khomentovsky et al., 1972; Shenfil, 1991; Sovetov, 1977; Tsakhnovsky, 1959], as thick as $3 \mathrm{~km}$. Correlating the molasse assemblage between the two zones using various methods presents little difficulty, although it 


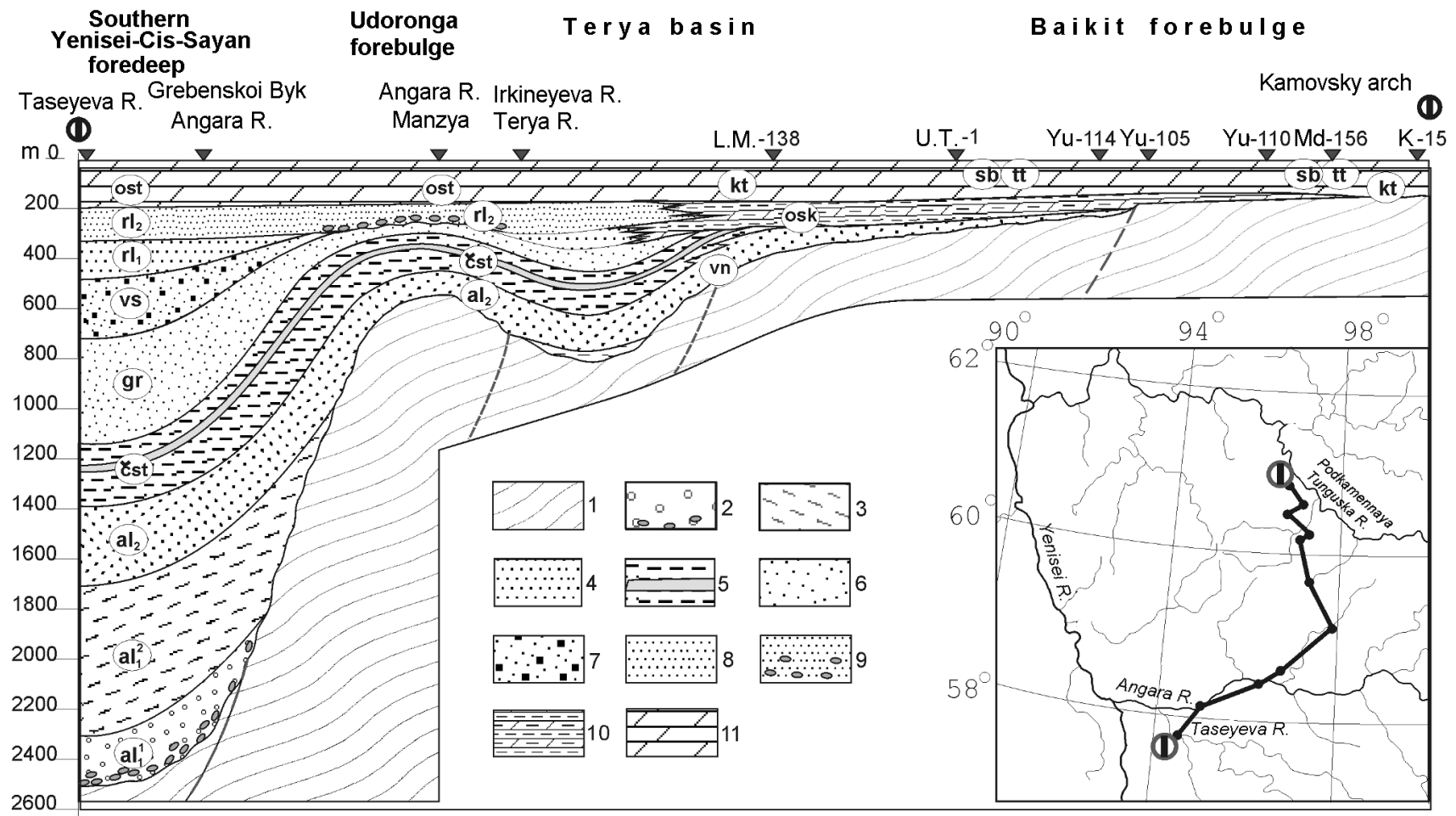

Figure 4. Paleo-transect across the southern Yenisei-Cis-Sayan foredeep and the Baikit uplift (transverse to the fold-and-thrust belt), modified after [Sovetov et al., 1996]. In late Aleshino time, various stratigraphic horizons of the molasse assemblage started onlapping basement and overlapping the foredeep. Assemblage facies change in the same direction, away from the principal (western) source of material, as the marine basin advances from the north. Reference shallow marine systems correspond to the Chistyakovo-late Vanavara marine transgression. The second major marine transgression (Redkolesnaya) was coeval to an orogenic pulse and to the pre-Oskobinsky break forming on a forebulge (Baikit anteclise). The third marine transgression, predating the pre-Katanga break, terminated in the deposition of a continuous carbonate and carbonate-sulfate cover.

Symbols: 1 - Riphean folded basement. Taseyeva Group. Lower fluvial assemblage, sedimentary systems of (2) braided gravel dominated stream, (3) meandering sand dominated stream and ephemeral branching channels, (4) wandering, meandering, and braided gravel dominated streams, pelite-sand terrestrial delta, and ephemeral (proluvial) streams on the Baikit uplift. (5) Medium- and shallow marine assemblage, sedimentary systems of foreshore and transitional beach zones and distal inner shelf zone. The Upper fluvial assemblage, sedimentary systems of (6) anastomosing pelite-sand dominated stream, (7) low-sinuosity stream with bars. The upper shallow marine assemblage, sedimentary systems: 8 - dominated by deposits of lower and middle foreshore beach zones, 9 - dominated by deposits of the upper foreshore beach zone; 10 - carbonate (stromatolite) and terrigenous carbonate-sulfate supratidal, lagoon deposits of the shelf and shoreline of the forebulge; 11 - carbonate-terrigenous, carbonate, and carbonate-sulfate deposits of the supratidal zone and various parts of the foreshore zone. Nomenclature of stratigraphic units (Formation, Subformation, Member): $\mathrm{Al}_{1}^{1}$ - Aleshino, Lower Subformation, Lower Member; $\mathrm{Al}_{1}^{2}$ - same, Upper Member; $\mathrm{Al}_{2}$ - same, Upper Subformation; Cst - Chistyakovo; Gr - Greben; Vs - Veselaya; $\mathrm{Rl}_{1}$ - Redkolesnaya, Lower Subformation; $\mathrm{Rl}_{2}$ - same, Upper Subformation; Vn - Vanavara; Osk - Oskobinsky; Kt - Katanga; Ost - Ostrovnaya; Sb - Sobinsky; Tt - Teter.

is for the first time that data proving its Vendian age have appeared (see below).

In the Patom foredeep (Nyuya-Dzherba basin), principal depositional events in the foreland basin are deduced confidently from the sedimentary systems of the Talakan and Parshino Groups, as thick as $1 \mathrm{~km}$. The Cisbaikalian and Patom foredeeps are separated by the North Baikal uplift, where the succession and thickness of deposits is similar to the reduced molasse sections on the Nepa-Botuoba forebulge. Marginal portions of the foredeeps of the Baikalian zone are likely to be concealed under the Late Paleozoic Baikal-Patom fold-and-thrust belt. 


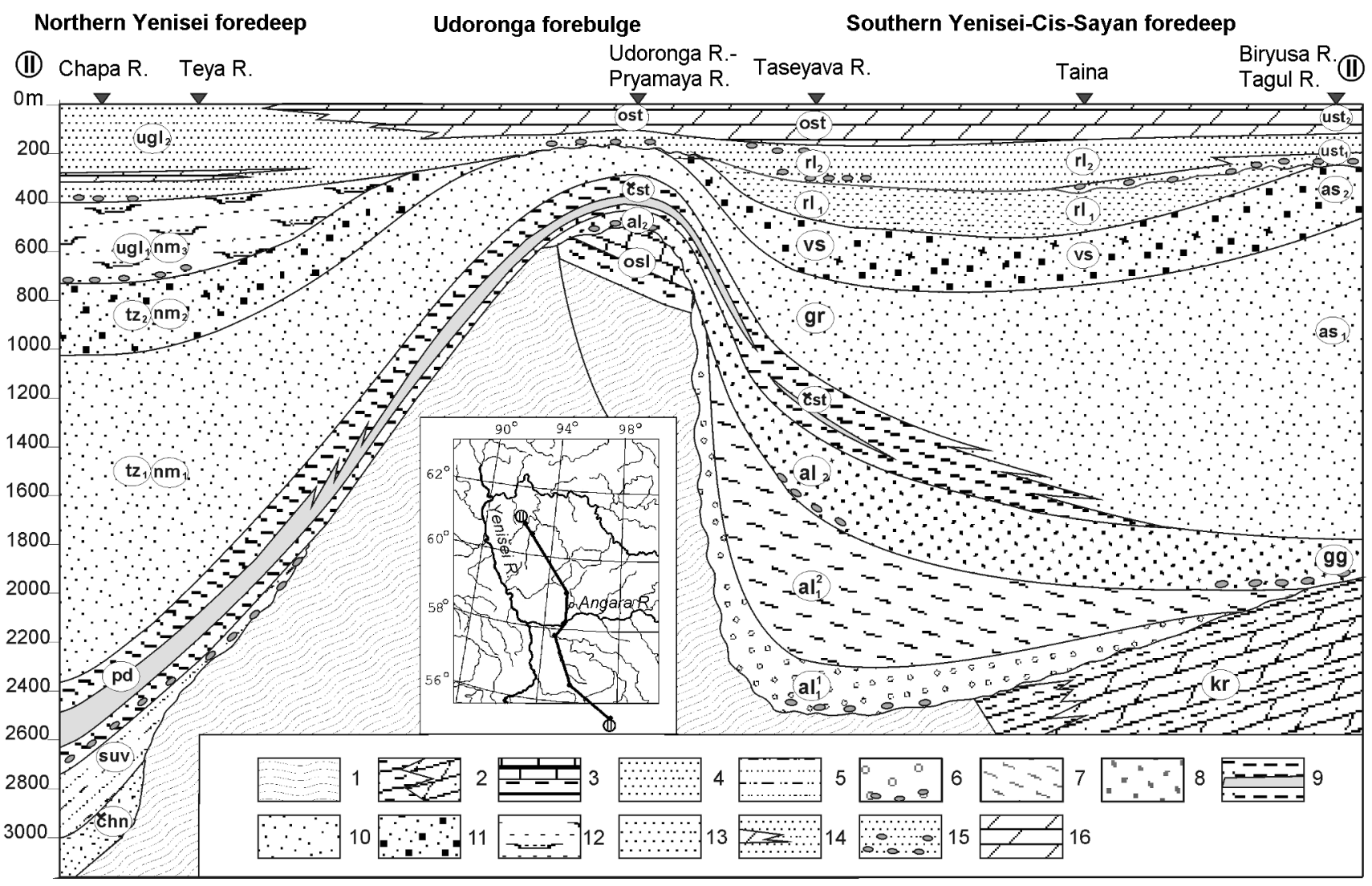

Figure 5. Paleo-transect across the southern Yenisei-Cis-Sayan foredeep (parallel to the fold-andthrust belt), after J. K. Sovetov and V. V. Blagovidov. The Late Vendian molasse assemblage rests with structural unconformity on Riphean strata of the continental margin basin and with minor angular unconformity on rock assemblages of Late Riphean aulacogens predating the formation of foredeeps. The foredeeps are separated from each other by an intramontane uplift with a reduced molasse section, the oldest deposits of the molasse assemblage occurring in the southern Yenisei-Cis-Sayan foredeep. From Late Aleshino time on, principal depositional phases and their coeval succession of sedimentary systems in the foredeeps were controlled by orogenic activity in the fold-and-thrust belt on the west of the Siberian craton.

Symbols: 1-4 - sedimentary Groups of Late Riphean aulacogens: 2 - Karagas, 3 - Oslyansky, 4 - Chingasan; the upper fluvial assemblage, sedimentary systems of braided sand-gravel dominated stream (5); the upper shallow marine assemblage, sedimentary systems of the foreshore zone (6). Nomenclature of stratigraphic units. Late Riphean Groups: Chn - Chingasan; Osl - Oslyansky; Kr - Karagas; Late Vendian Chapa (Nemchansky) Group, Formations and Subformations: Suv - Suvorovsky; Pd - Podyemsky; Tz 1 - Lower Taezhninsky (Lower Nemchansky), $\mathrm{Tz}_{2}-\mathrm{Nm}_{2}-$ Upper Taezhninsky (Middle Nemchansky); $\mathrm{Ugl}_{1}-\mathrm{Nm}_{3}$ - Lower Uglovsky (Upper Nemchansky), $\mathrm{Ugl}_{2}$ - Upper Uglovsky. Late Vendian Oselkovaya Group, Formations and Subformations: Gg - Georgievsky; As 1 - Lower Aisa; $\mathrm{As}_{2}$ - Upper Aisa; Ust ${ }_{1}$ - Lower Ust-Tagul. Other symbols, as in Figure 4.

\section{Tillites at the Base of the Oselkovaya Group in the Cis-Sayan Zone and Position of the Lower Boundary of the Vendian on the Southwestern Siberian Craton}

The issue of stratigraphic position of Late Precambrian sedimentary successions in cratonic margin depressions on the southwest of the Siberian craton lies in that, until recently, there had been no strict physical or paleontologic evi- dence to correlate these successions to standard Riphean and Vendian sections. The totality of evidence for geochronologic age of the Karagas and Oselkovaya Groups and their stratigraphic correlatives on the Yenisei Ridge, in Cisbaikalia, and in the interior of the Irkutsk amphitheater was largely based on lithologic and petrographic data without due account for sedimentary systems or for how they succeed each other through the evolution of rift-related and foreland basins. The use of questionable paleontologic remains (phytoliths and microfossils) for correlating and interpreting the age of 
sedimentary successions has always been debatable, leading different researchers to dissimilar results. Without enlarging on previous studies, let us emphasize the principal variances between different correlations.

In the wake of the regional stratigraphic research conducted by the large team from the Institute of Geology and Geophysics (Russian Academy of Sciences, Siberian Division), a viewpoint took root, which was supported by geologists involved with state geological surveying, that the major Precambrian Karagas and Oselkovaya Groups of the CisSayan zone belong to the Riphean, whereas only the overlying Ust-Tagul Formation and its stratigraphic counterparts are correlative to the Vendian (Yudomian) [Khomentovsky et al., 1972]. This concept has been consistently refined by the writers just mentioned and their colleagues in all their subsequent publications. The concept draws mainly on systematic lithologic correlation of closely coeval sedimentary successions along the perimeter of the Siberian craton, with the ultimate purpose of correlating them to the regionally extensive counterpart of the Vendian in Siberia-the $\mathrm{Yu}-$ doma Group of the Yudoma-Maya basin. This correlation has led to the notion of a singular temporal phase of the Late Riphean, termed "Baikalian," well expressed in the Baikalian Group of Cisbaikalia - assumedly, a precise correlative to the Karagas and Oselkovaya Groups of the Cis-Sayan zone [Khomentovsky, 1990]. According to this notion, the terrigenous succession at the base of cratonic cover on forebulges in the interior of the Siberian craton, correlative to the Yudomian, must overlie not only the Karagas, but also the Oselkovaya Group in the Cis-Sayan zone. A sharply dissenting viewpoint on the correlation of Late Precambrian successions of deep marginal basins of the Siberian craton to relatively thin deposits on inner uplifts was proposed by [Sovetov, 1977]. According to our correlation, which is based on a comparison of petrographic compositions of psammites, terrigenous deposits in the interior of the Siberian craton thicken dramatically (an order of magnitude) toward the cratonic margin and make up a continuous molasse formation. The molasse was correlated to the Yudoma Group, and, hence, the marginal molasse-filled foreland basin should be dated to the Vendian. Sedimentologic studies on the western Yenisei Ridge have convinced us that the "lower marine assemblage" of the molasse should be attributed to the Vendian as well [Sovetov et al., 2000]. However, both the analysis of sedimentary systems and sequence-stratigraphic correlation failed to constrain directly the age of the molasse and the foreland basin. Such constraints could only be provided by indisputable finds of multi-cellular faunal remains, by physical age of minerals syngenetic to the sediments, by the analysis of $\delta \mathrm{C}^{13}$ isotope in carbonates, and by sedimentologic evidence for certain physical processes in a narrow stratigraphic range (such as glaciations).

By the mid 19 hundreds, Vendian glacial deposits had been spotted and identified on nearly all the Precambrian cratons in Europe, Asia, Australia, Africa, and North and South America [Chumakov, 1978]. The only remaining exception was the Siberian craton. This was noted by all the researchers, including [Sovetov, 2001a]. In a methodological study on the Vendian System, Sokolov [1997] also noted this fact and predicted the prospect of finding tillites of the Ven- dian (Laplandian) glaciation in deep basins along the margin of the Siberian craton.

Much promise for such finds was held by the Marnya (basal) and Uda Formations of the Oselkovaya Group of the Cis-Sayan foredeep. Coarse clastic deposits at the base of the Late Precambrian Oselkovaya Group of the Cis-Sayan zone have been known since the pioneering studies on these strata [Khomentovsky, 1945], and their existence was further verified by geological surveys and specialized stratigraphic investigations [Khomentovsky et al., 1972]. All the workers agreed that a break existed between the Oselkovaya and Karagas Groups, as evidenced by basal conglomerates and breccias in the Oselkovaya Group [Bragin, 1984; Khomentovsky et al., 1972; Mordovsky, 1956, 1958; Pavlovsky, 1954; Tsakhnovsky, 1959].

Our own 2001 study on this boundary, performed two months after the Irkutsk conference on supercontinents, at which geodynamic implications of Neo-Proterozoic deposits were discussed, was inspired by the conviction that unconformity between the Karagas and Oselkovaya Groups is the Riphean/Vendian boundary. Our field campaign was intended to spot glacial deposits, widespread in Early Vendian strata on Precambrian cratons and microcontinents and customarily attributed to orogeny. The search and specialized observations were successful, establishing in the Oselkovaya Group the first solid sedimentologic evidence for glacial deposits and two types of tillites, which we named, according to their stratigraphic and geographic positions, "Ulyakh tillite" and "Plitninskii tillite" (coming in three horizons).

The lower part of the Oselkovaya Group in the catchment area of the Uda River is divided in two Formations, Marnya (lower) and Uda [Khomentovsky et al., 1972]. The most detailed stratigraphic subdivision of these Formations was performed by Bragin [1984]. To avoid confusion in identifying lithologically similar members, we introduced names of our own for members with stratotypic boundaries and sections; hence, the nomenclature of stratigraphic units of the Formations and its sedimentologic validation are new (Figure 6). Deposits of the Marnya and Uda Formations are closely interrelated. The regional-scale issue of where the boundary of the Formations within the continuous sedimentary assemblage should be placed, is approached in different ways [Bragin, 1984; Khomentovsky et al., 1972]. In a composite section, and as correlatives, the following units are recognized in the Marnya Formation, from bottom to top:

The Ulyakh Member, composed of boulder diamictites (tillites) with an exposed thickness of $14 \mathrm{~m}$. According to geological survey data, the Ulyakh Member unconformably overlies the Tagul Formation of the Upper Riphean Karagas Group, but its lower contact is not exposed. The Member crops out on the left side of the Uda River, $1.2 \mathrm{~km}$ upstream of the Ulyakh River mouth.

The Tygnei Member, made up of black pyritized bituminous siltstones and sandstones, filling in minor channels, and finely laminated siltstones of lake interior, 80-90 m thick. The lower and upper portions of the Member are exposed in low outcrops on the right side of the Uda River, 1.5$2 \mathrm{~km}$ downstream of the Tygnei River mouth. The Member makes up the lower, poorly exposed slope portion at the $\mathrm{Oz}$ erki locality, in the interfluve between the Marnya and Ognit 


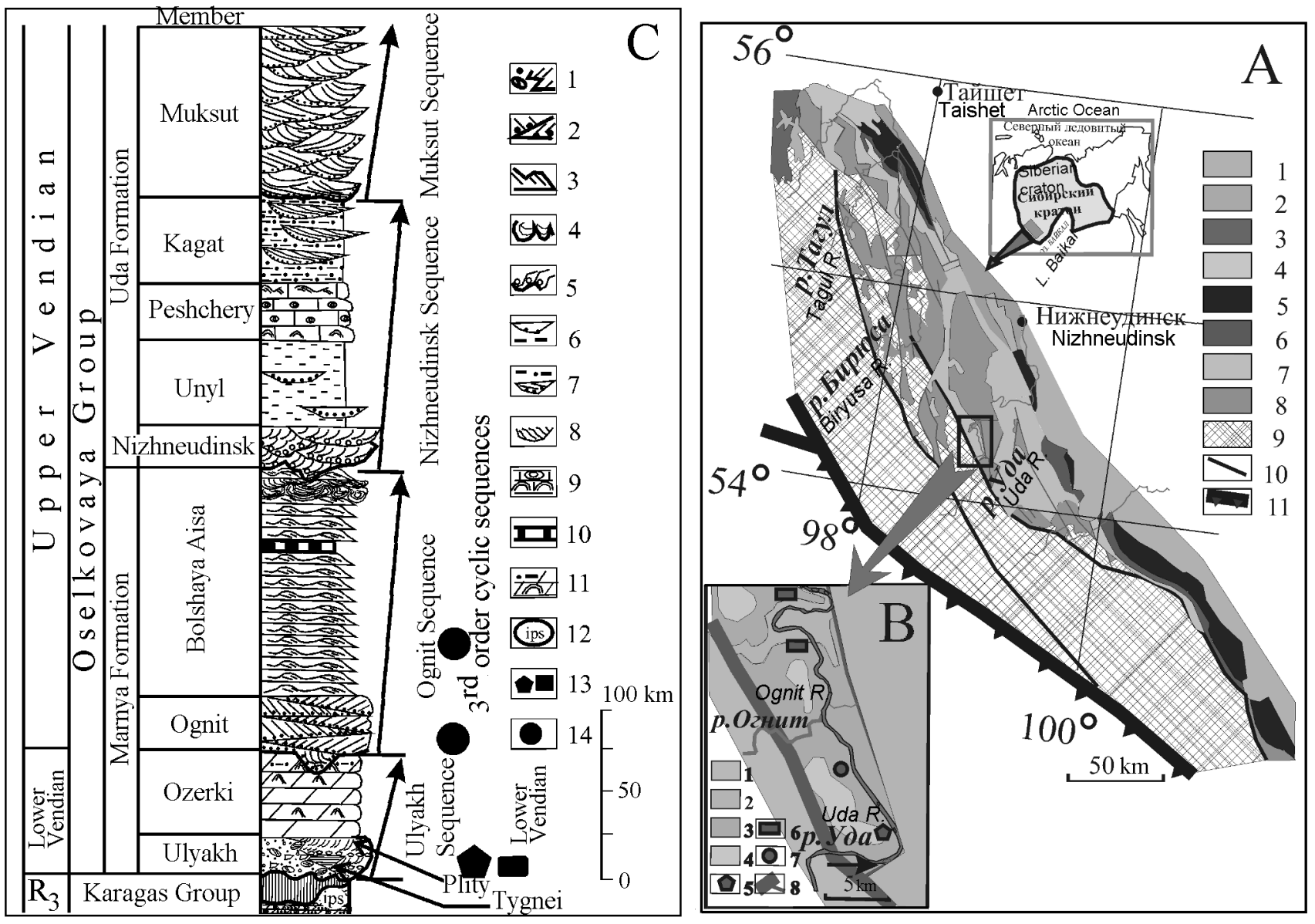

Figure 6. Scheme showing the Vendian foreland basin of the Siberian cratonic margin and distribution of glacial deposits within it.

(A) Cis-Sayan foredeep. Post-Vendian deposits: 1 - Lower Jurassic, 2 - Lower Carboniferous, 3 - Middle Devonian, 4 - Lower Ordovician, 5 - Lower Cambrian. Lithostratigraphic units of Vendian deposits: 6 - Ust-Tagul Formation, 7 - Oselkovaya Group (Marnya, Uda, and Aisa Formations). Pre-Vendian deposits: 8 - Karagas Group, Early Neo-Proterozoic, 9 - metamorphic and igneous basement assemblages. Faults: 10 - post-Vendian, 11 - marginal tectonic suture of the Siberian craton.

(B) Marnya segment of the Cis-Sayan foredeep. Pre-Vendian rocks: 1 - metamorphic and igneous basement, 2 - Karagas Group. Lower stratigraphic units of the Vendian (Oselkovaya) molasse: 3 - Marnya Formation and lower portion of the Uda Formation, 4 - upper portion of the Uda Formation. Finds of tillites and traces of nonskeletal faunas: 5 - diamictites (tillites) at the base of the Ulyakh Member, 6 - faceted boulder breccias at the base of the Plitninskaya Member,7 - traces of vital activity of nonskeletal Metazoa (ichnofossils), 8 - faults, principal and subsidiary.

(C) Assemblage of deposits of the lower portion of the Vendian (Oselkovaya) molasse. 1 - diamictites (tillites), glaciofluvial faceted boulder breccias and eolian sandstones, lacustrine siltstones and bituminous shales. Sandstones of marine environments: 2 - nearshore, 3 - storm-dominated, 4 - hurricane current-dominated. Gravelstones, sandstones, and siltstones of terrestrial and transitional environments: 5 - fluvial (cratonic), 6 - deltaic, 7 - fluvial (orogenic), 8 - fluvial, recording main stages of fluvial plain progradation. Limestones and dolomites of (9) microphytolith bars and stromatolite buildups, (10) distal shelf silt zone, and (11) postglacial (cap) laminated, bioherm, and of sand waves; 12 - units of the Karagas Group and depth of erosion in molasse. Stratigraphic position of (13) tillites and (14) finds of ichnofossils and molds of nonskeletal Metazoa. Three eustatic cycles (arrows) with intervals of deposits of sea-level lowstand, rapid marine transgression, and sea-level highstand. 
Rivers. This Member is likely to replace the Ulyakh Member on the northeast, while being in turn replaced by the Plitninskaya Member on the opposite side.

The Plitninskaya Member, composed of faceted boulder breccias and massive eolian white quartz sandstones, 20$35 \mathrm{~m}$ thick. The stratotype of the Member is situated on the right side of the Uda River, in the Plity locality, where three breccia beds occur; it is also exposed on the left side of the Uda River, in the Ozerki and Uraly locality. The Plitninskaya Member is a stratigraphic counterpart to the Ulyakh Member.

The Ozerki Member, composed of thin flat-laminated, wavy laminated, silty and sandy, granular (microphytolith) and stromatolite dolomites, 50-60 m thick. The stratotype of the Member is situated on the left side of the Uda River, in the Ozerki locality. The Member is also exposed on the left side of the Uda River, over a stretch of $10 \mathrm{~km}$ from the Ognit to the Ulyakh River.

The Ognit Member, consisting of dark gray quartz sandstones (orthoquartzites) of varying grain size, occasionally gravelly, with bed forms indicative of dunes, sand shelf veneer, and sand waves, ca. $30 \mathrm{~m}$ thick. The Member is exposed continuously on the left side of the Uda, from the mouth of the Ognit to the Pshenei River, and opposite the mouth of the Bolshaya Aisa River. In the Plity locality, this member is lacking. The Member overlies the Ozerki Member, in places with sharp erosion and topographic incision at the base.

The Bolshaya Aisa Member, composed of sandstones of varying grain size and thickness with hummocky, flat, and, less frequently, deformed coarse cross laminations of different subzones of the storm wave zone, 105-165 m thick. Siltstones are subordinate, and granular limestones are sporadic. The Member has been established on the right side of the Uda, opposite the mouth of the Bolshaya Aisa River, and its full stratigraphic range is exposed in many sections, including those on the left side of the Uda, opposite the Pshenei River, on the left slope of the Ognit near its mouth, and at the Plity and Muksut localities. In places, it unconformably overlies the lower units (in particular, the Plitninskaya Member, as at the Plity locality).

The total thickness of the Marnya Formation is 280$380 \mathrm{~m}$. Two stratigraphic types of the Marnya Formation, as established by Bragin [1984], have been ascertained: (1) that of the Ozerki locality, where the Karagas Group is overlain successively by the Ulyakh and Tygnei Members, and (2) that of the Plity locality, where both lower members are lacking, the Ipsit Formation of the Karagas Group being overlain by faceted boulder breccias of the Plitninskaya Member. In the Plity section, the Ozerki and Ognit Members are eroded, the Bolshaya Aisa Member overlying the Plitninskya Member.

The Uda Formation has been subdivided into the following Members:

The Nizhneudinsk Member, composed of white gravelly quartz-feldspathic sandstones and gravelstones of channel origin, $17-21 \mathrm{~m}$ thick. The stratotype of the Member is located on both sides of the Uda near the mouth of the Bolshaya Aisa, and is also exposed opposite the mouth of the Pshenei River, in the Plity and Muksut localities, on the left side of the Chelota River, and it overlies, with erosion and deep incision at the base, the Bolshaya Aisa Member.

The Unyl Member, composed of fluvial siltstones with lenses of sandstones of variable grain size deposited in subsidiary channels, 25-100 m thick. The Member was established on the water divide between the Uda and Unyl, and it is also exposed on both sides of the Uda between the Bolshaya Aisa River and the Gladkii Mys locality, opposite the mouth of the Pshenei River, on the left side of the Chelota River. Because of the fine grain size of the deposits, this Member is exposed poorly; deltaic and floodplain depositional environments are reconstructible from isolated outcrops.

The Peshcherninskaya Member, composed of dark gray to black bituminous, stromatolite, microphytolith, and granular limestones, with oblique sandbar layering and wavy and small-scale hummocky cross stratification, over a short distance gives way to massive cavernous dolomites, 7-30 m thick. The stratotype of the Member is situated on Peshcherny Utes (Cave Cliff) at the Plity locality, and its parastratotype, on the left side of the Uda, in the interfluve between the Marnya and Ognit. This Member is also exposed on both sides of the Uda, between the Bolshaya Aisa River and the Gladkii Mys locality.

The Kagat Member, consisting of packages of floodplain, delta plain, and levee fluvial siltstones and massive crosslaminated sandstones of principal and intercept channels, 50-70 $\mathrm{m}$ thick. The stratotype of the Member is situated on the left side of the Uda River, at the Muksut locality, opposite the mouth of the Kagat River, and it is also exposed at the Plity locality.

The Muksut Member, composed of massive crosslaminated channel sandstones with subordinate channel bar sandstones and siltstones, whose wide spread points to regionally extensive progradation of fluvial systems onto the craton and to the appearance of a sedimentary assemblage of major stream valleys, 100-150 m thick. The stratotype of the Member is situated on the left side of the Uda, at the Muksut locality, and it is also exposed excellently in the Uda riverside bluffs between the mouths of the Gambur and Muksut, at the Gladkii Mys locality. This Member was justly considered as an important marker horizon for the molasse assemblage [Bragin, 1985]. Fluvial deposits similar to the Muksut and Kagat ones, but varicolored and redcolored, are unanimously attributed to the Aisa Formation, although sedimentologic analysis shows the two upper Uda members jointly with the Aisa Formation to compose the continuous so-called "upper terrestrial assemblage" of molasse, established earlier on the Yenisei Ridge [Sovetov and Blagovidov, 1998]. The total thickness of the Uda Formation in the range of the established Members is $200-550 \mathrm{~m}$. The stratigraphic interval between the base of the Ozerki Member and the top of the Peshcherninskaya Member was attributed to the "lower marine assemblage of the Vendian molasse" earlier [Sovetov and Blagovidov, 1998].

The Ulyakh tillite is a stratigraphic counterpart to the Ulyakh Member, assumedly resting on eroded basement (i.e., on the Tagul Member of the Karagas Group), although the contact itself is not exposed. The Ulyakh tillite has a set of features typical of glacial deposits. These features are 
classed into ten groups, (1) textural: diamict (mixtite) texture of the sedimentary body, with clay-silt-sand matrix and fragments ranging from gravel to boulder; unsorted faceted boulder breccias with sand-gravel fill; (2) sedimentologic: the boundaries and succession of sedimentary bodies ranging from homogeneous coarsely stratified diamictite to eskertype glaciofluvial channeled diamictite, and orientation of channels; (3) structural: narrow vertical diamictite-filled crevasses, nest-like clusters of clasts, and boulder pavements; (4) diamictite being overlain abruptly by cap dolomites; (5) grain size distribution: clast size, bullet clasts, and matrix texture; (6) clast structures, abrasion, and polishing; glacial striation of clasts and striation orientation; (7) petrographic: clast lithology and the presence of exotic rocks, missing from the deposits immediately underlying the Karagas Group; (8) paleogeographic: the character of bedrock and topography on which tillites rest; directions of glacier advance and of glaciofluvial streams; (9) the arrangement of rock assemblages: lateral links of genetically similar deposits and successions of deposits attributable to eustatic sea-level changes; (10) controlling and comparative: the lack of depositional features independent of glacial environments, such as subaerial and submarine debris flows and lachars or tectonic, volcanic, and impact breccias; similarity to the models for firmly established and well-understood glacial deposits.

Architecturally, the Ulyakh diamictite is similar to the typical tillites, such as I have observed in the Vendian Baikonur and Rangsky Formations of the Greater Karatau Range and in the Dzhetymtoo Formation of the Central Tien Shan. First and foremost, the clasts are unsorted by size or shape. The Ulyakh tillite contains some comparatively well-"rounded," faceted, and chipped boulders up to $70 \mathrm{~cm}$ across, along with perfectly sharp-edged clasts and debris. Overall, the diamictite is matrix-dominated, only glaciofluvial streams having a roughly equal proportion of matrix and clasts. Most clasts have unimodal shape distributions (faceted, pentahedral, tetrahedral, pyramidal, and bullet) and carry glacial striations, occasionally in two or three directions, and polished hollows and facets. The degree of abrasion does not depend on clast size; both thoroughly abraded loaf-shaped fragments $3-5 \mathrm{~cm}$ across and faceted blocks $30-50 \mathrm{~cm}$ across are encountered.

Clast lithologies are dominated by fine- and thin-grained quartzites (sandstones), similar to the Ipsit Formation quartzites of the Karagas Group with storm-generated features. Besides quartzites, one finds Karagas Group dolomites, including stromatolite ones, as well as sandstones, basic and acid effusives, biotite granite-gneisses, and granites.

Glaciofluvial streams are encountered at two levels in the upper part of diamictite ( $5 \mathrm{~m}$ from the top) and are up to $6 \mathrm{~m}$ in width and up to $2 \mathrm{~m}$ in thickness. These are steep-walled crevasses with subsidiary sharp scours at the bottom, passing laterally into linear rock pavements. Scanty measurements give a channel plunge direction, $\mathrm{S} 230^{\circ} \mathrm{W}$, that coincides with one glacial striation system - the plunge of trough axes in the Plitninskii glaciofluvial sandstones. The breccia-filled crevasses, as wide as $30 \mathrm{~cm}$ and as deep as $150 \mathrm{~cm}$, have uneven sides and occur in the upper part of the diamictite, at the level of eskers. The Ulyakh tillite is spread on the south of the study area, giving way northward and eastward to the Plitninskii tillite. Structurally, the Ulyakh tillite resembles subglacial deposits of ground moraines.

The Plitninskii tillite (faceted boulder breccias, FBB) was established in the stratotype of its homonymous Member, at the Plity locality, and further south, on the left side of the Uda River, at the Uraly and Ozerki localities. Stratigraphically, the Plitninskii tillite, based on the correlation of its enclosing and overlying members, corresponds to the Ulyakh diamictite jointly with the package of channel deposits. Its contact with bedrock was documented at the Plity locality. Here, coarse faceted boulder breccias (with fragments as large as $1.5 \mathrm{~m}$ ) rest, seemingly conformably, on the hummocky surface of storm-reworked deposits of the Ipsit Formation and consist of fragments of the Ipsit fine-grained quartz-feldspathic sandstones (orthoquartzites). Clearly enough, before being redeposited, the Ipsit sediments had been lithified, responding to lateral pressure as brittle rocks. The Plitninskii tillites are not diamictites, inasmuch as the breccia is devoid of matrix, whose place is occupied by volumetrically minor sand and sandgravel fill. In terms of sorting, shape of clasts, and degree of clast rounding, these rocks cannot be classed with breccia and/or conglomeratic breccia in the strict sense. The mixture of sharply angular and partly rounded pebble-like fragments of various sizes, showing no preferential orientation, is best defined as "faceted boulder breccia." This term points to (1) the clasts being chipped, ground, and polished by the rock-sand mass and ice, (2) the presence of clasts of sharply variable size, including large blocks that, when rounded, resemble boulders; (3) the initial shape of clasts being related to smashing, ploughing, detachment, and collapse of bedrocks. Faceted boulder breccias make up massive beds (1-13 m thick) of densely packed clastic material resembling a bulldozed pile. Fragments show no size differentiation, sand having penetrated down into the loose mass later, from the overlying fluvial strata. Along with massive FBBs, encountered are layers with coarse clastic material, clearly redeposited and making either isolated fragments or continuous sand-debris mixtures. In the stratotypic locality, FBBs make up three beds (horizons) that thicken abruptly to the east and southeast, the two lower beds ultimately merging together. Some 250-300 m to the southwest within the same exposure, FBB beds become separated by sandstones, and several additional minor beds appear. The maximum thickness of the lower continuous FBB bed is $13 \mathrm{~m}$. The pseudoconformable onlap of the lower FBB bed on bedrocks is due to the layered sequence being peeled off by the ice "bulldozer" along plains that are parallel to depositional surfaces. The offscraping of clastic material was accompanied by layers being finned up and by the FBB wedging into the underlying sequence.

Clastic material of the Plitninskii tillites, just as in the Ulyakh tillite, is characterized by peculiar faceted and polished shapes resembling bullets. The shape of clasts was scrutinized in collections picked from the FBB, and it is remarkably persistent from place to place throughout the Plitninskii tillite at the Plity, Uraly, and Ozerki localities. However, striated rocks are considerably less abundant in the FBB than in the diamicts. 
The Plitninskii tillite, which comes in three beds, spans the lower portion of the Plitninskaya Member, totaling ca. 20 in thickness, and is closely associated with eolian sandstones. This relationship is ascertained from the reverse proportionality between thickness variations of the FBB and sandstones and from the fact that FBBs occur at the base of glaciofluvial cycles overlain by eolian sandstones with clasts redeposited onto dune foresets. Taken together, these data, along with structural observations, indicate that the Plitninskii tillite was laid down in a glaciofluvial environment with dune eolian fields. While the Ulyakh tillite, sedimentologically, is similar to ground moraines (i.e., chaotic masses deposited by subsurface ice flow), the Plitninskii tillite is comparable to deposits of fluvial debris cones whose lobes reached into terrestrial water bodies. Measured directions ( $n$ $=31$ ) of principal wind flows indicate that sand was windblown in westerly and southwesterly directions-i.e., from the interior to margin of the craton. These paleotransport directions are consistent with the orientation of glacial striations on boulders in the Ulyakh tillite and with the plunge of subglacial channel beds, and they prove directly that the glaciation was continental, which implies that we are dealing with an intracratonic ice sheet [Chumakov, 1978]. The intracratonic source of material, which came into play after the removal of ice load and isostatic uplift of central portions of the craton, is clearly recorded from flow directions in the fluvial Nizhneudinsk Member, perfectly identical to the paleodirections of glacial transport and to arkosic composition of the clastic material.

The corollary that glaciation was continental in type is in concert with my belief that Early Oselkovaya marine transgressions advanced from southwestern marginal seas onto the Siberian craton. This conclusion is supported by the broad occurrence of diamictites, conglomeratic breccias, and unsorted gravelstones at the base of the Taseyeva, Chapa, Vanavara, and Nepa Groups. The basal member of the Podyemsky Formation of the Chapa Group in the eastern Yenisei foredeep (catchment area of the Teya River) is composed of a diamictite whose clasts range in size from gravel to blocks and of rock fragments derived from the underlying Late Riphean Pogoryui Formation. Similar mixtite deposits and casts of striations and grooves on the underlying metamorphosed turbidite sequence of Late Riphean age are encountered at the base of the Stolbovsky Formation of the Chapa Group in the western Yenisei foredeep (the Nizhnyaya Surnikha River catchment area) [Sovetov et al., 2000]. Diamictites and unsorted sandy gravelstones compose the basal Member V and Member VI of the Vanavara Formation and rest on the Baikit uplift in tunnel valleys as deep as 20-30 m, trending $\mathrm{W}$ to SW. A similar basal member (10-20 m thick) is found at the base of the Taseyeva Group on the Udoronga uplift, and its stratigraphic counterparts, in the Upper Subformation of the Aleshino Formation of the southern Yenisei foredeep. Basal strata of the Lower Nepa Subormation on the Nepa-Botuoba uplift and its southeastern slope (Upper Chona 2, Bezymyanny, the Talakh Formation) consist of unsorted gravel-sand mixtures resting on eroded basement surface. All the mentioned tilloids of the Yenisei Ridge and Baikit-Nepa forebulge, just as the Ulyakh and Plitninskii tillites, are overlain by carbonate and terrigenous deposits left by the first regionally extensive marine transgression. Deposition of synchronous glaciofluvial sediments involved incision of narrow valleys and clastic transport from cratonic interior into foredeeps [Lebedev and Chernova, 1996; our own measurements from the Aleshino, Podyemsky, Marnya, and Uda Formations on the Yenisei Ridge and in the Cis-Sayan zone]. Apparently, puddingstones that rest on basement in the cratonic interior, on the southeastern slope of the Anabar anteclise [Shishkin, 1999], should also be attributed to the glacial horizon. The totality of evidence provides a further proof that glaciation of the Siberian craton was intracratonic in type, just as the Laplandian glaciation of the Eastern European craton [Chumakov, 1978, 1985].

Overall, terrestrial glacial sedimentation in marginal portions of the craton came to an end after the deposition of the Plitny Member eolian sandstones, a moment in time that is marked by the dramatic transgression of the marine basin and formation of the so-called cap dolomites. The synchroneity of melting of the Marnya ice sheet and marine transgression points to a global event - a rise of the level of the world ocean - and is correlatable to coeval glaciations on many continents. The glacial epoch known as Varangian (Laplandian) [Chumakov, 1978] took place in the Early Vendian, and the Marnya Formation tillite belongs to this epoch. This is indirectly evidenced by the ichnofaunal assemblage reported from above the tillite, in marine deposits of the Ognit Member of the Marnya Formation.

Until now, no remains or molds of multi-cellular marine faunas have been reported from the foredeeps of the Siberian craton in deposits older than the Ust-Tagul Formation and its correlatives - i.e., older than the uppermost molasse horizons. Here, sporadic mollusk molds [Chechel, 1976] and ichnofossils [Sovetov, unpublished data] have been encountered. Questionable remains have been recovered from the Motsky (Nepa) Group by oil exploration drilling in the interior of the Irkutsk amphitheater; these finds were attributed to the Vendian [Sokolov, 1975] or Cambrian [Akulcheva et al., 1981], although most workers viewed their enclosing strata as being younger than the molasse assemblage of the CisSayan foredeep. The sedimentologic study of the molasse involved searching for multi-cellular faunal remains in the lowermost marine beds of the Oselkovaya Group in the CisSayan foredeep, which sit $2.5-3 \mathrm{~km}$ up the stratigraphy from the base of the Cambrian (as per the officially approved unified stratigraphic scheme). This search for faunal remains in quartz sandstones of the supra-tillite portion of the section has been successful, yielding an abundant ichnofossil assemblage near the base of the Ognit Member. The fossil finds collected from bedding surfaces and between them largely belong to the genus Planolithes and currently are being studied. The very fact of extensive vital activity of multi-cellular organisms, clearly related to deglaciation and advent of marine environments, is highly likely to suggest that the early Oselkovaya tillite is Vendian in age, and glaciation of the Siberian craton belongs to the Laplandian glacial epoch [Chumakov, 1978, 1985; Sokolov, 1997]. The tillites and tilloids of the Late Riphean Sturtian glacial epoch occur in totally different (rift-related) paleotectonic settings and, on the Siberian craton (Chividinsky and Dzhemukan For- 


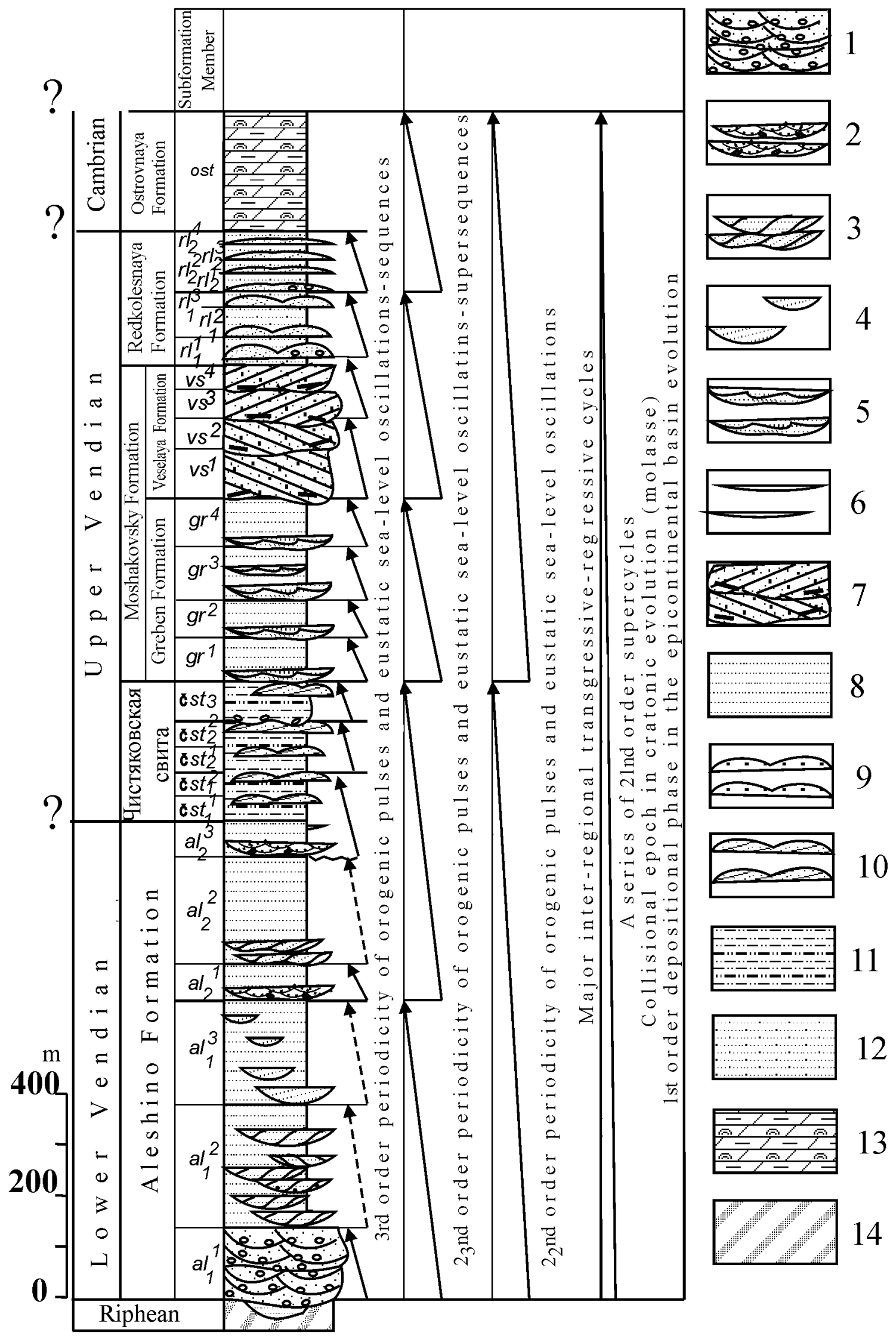


mations), they undoubtedly lie stratigraphically below the molasse successions.

These new data have suggested a revision of the early evolutionary history of the foreland basin of the Siberian cratonic margin.

\section{Stratigraphy of the Vendian Molasse of the Siberian Craton and Correlation of Principal Depositional Events}

The type section of the Vendian molasse has been studied in greatest detail on the southeast of the Yenisei Ridge, in the southern Yenisei-Cis-Sayan foredeep [Sovetov and Blagovidov, 1998]. On the southeastern Yenisei Ridge, the Vendian molasse assemblage is comprised of the Taseyeva Group, composed of terrigenous, largely redbed deposits. A study that is detailed enough from the standpoint of present-day sedimentology has been carried out on two sections of the Taseyeva Group in its stratotypic locality - on the southeast of the Yenisei Ridge, at the Taseyeva River (near the mouth of the Usolka R.) and at the Angara River (at Greben Cliff) (Figure 7). The Taseyeva deposits make up a continuous assemblage of Late Precambrian molasse, resting with structural unconformity on nonuniform, in terms of its age, basement, and formed coevally on the southwestern and southern margins of the Siberian craton as a thick wedge of terrigenous deposits and as a relatively thin cover, in its interior. The sedimentologic study of the stratotypic section of the Taseyeva Group has afforded its division into five Formations, from bottom to top: Aleshino $(930 \mathrm{~m})$, Chistyakovo (270 m), Greben (413 m), Veselaya (233 m), and Redkolesnaya $(295 \mathrm{~m})$. The Aleshino Formation, composed of redbed clastic deposits, is divided into two Subformations. The lower Subformation of the Aleshino Formation $\left(\mathrm{Al}_{1}\right)$ comes in three units: (1) Member one $\left(\mathrm{Al}_{1}^{1}, 140 \mathrm{~m}\right)$, finepebble quartz conglomerates, cross-stratified gravelstones, and very coarse to coarse-grained sandstones; (2) Member two $\left(\mathrm{Al}_{1}^{2}, 240 \mathrm{~m}\right)$, alternating packages of massive coarse- to fine-grained oblique cross-laminated sandstones and thinly platy fine-grained sandstones and siltstones with flat stratification; (3) Member three $\left(\mathrm{Al}_{1}^{3}, 180-200 \mathrm{~m}\right)$, massive unsorted silty sandstones and siltstones with poorly developed bedding-plane parting. The Upper Subformation of the Aleshino Formation $\left(\mathrm{Al}_{2}\right)$ comprises three units: (1) Member one $\left(\mathrm{Al}_{2}^{1}, 70 \mathrm{~m}\right)$, alternating thin layers of coarse- to fine-grained cross-laminated sandstones, massive unsorted non-laminated and platy, with sluggish current lamination, sandstones and siltstones, containing at its base several beds of gravelly coarse-grained sandstones; (2) Member two $\left(\mathrm{Al}_{2}^{2}\right.$, $210 \mathrm{~m}$ ), whose lower part consists of massive coarse-grained oblique cross laminated and cross laminated sandstones with siltstone intraclasts, and upper, of thin alternating layers of fine-grained sandstones and siltstones; (3) Member three $\left(\mathrm{Al}_{2}^{3}, 70 \mathrm{~m}\right)$, whose lower part consists of massive very coarseto coarse-grained thickly cross-stratified sandstones, and the upper, of thin alternating layers of thinly cross-laminated fine-grained sandstones and siltstones, in places with sluggish current lamination.

The Chistyakovo Formation, composed of gray-colored and varicolored clastic deposits, comes in three units: (1) Member one (Cst $1,93 \mathrm{~m}$ ), black and dark gray siltstones and mudstones with occasional beds of coarse-grained cross-laminated sandstones and sporadic layers of clayey dolomite; (2) Member two ( $\mathrm{Cst}_{2}, 99 \mathrm{~m}$ ), whose lower part consists of dark gray siltstones and wavy laminated sandstones with storm-generated structures, and upper, of white and light gray massive coarse- to fine-grained sand dune foresets; (3) Member three ( $\mathrm{Cst}_{3}, 78 \mathrm{~m}$ ), whose lower part is composed of varicolored sandstones of varying grain size with storm-generated structures, and upper, of thinly alternating layers of red- and varicolored siltstones and sandstones and gray coarse-grained sandstone with wavy trough-like bedding and numerous desiccation cracks.

Within the stratigraphic range of the Moshakovsky Formation (in the strict sense), we have established two new Formations, Greben and Veselaya. The name of "Greben Formation" (Gr), in the section at the Angara River in the Shalygino anticline, was given to the lower redbed sandstonesiltstone portion of the Moshakovsky Formation, lying gradationally on the Chistyakovo Formation. The name is derived from Mt. Greben. The upper, sandstone part of the Moshakovsky Formation was named "Veselaya Formation" (Vs) after Mt. Veselaya within the same structure. The Greben Formation abounds in siltstone and mixed siltstonesandstone deposits, forming four cyclically built members: (1) $\mathrm{Gr}_{1}(90 \mathrm{~m}),(2) \mathrm{Gr}_{2}(68 \mathrm{~m}),(3) \mathrm{Gr}_{3}(106 \mathrm{~m})$, and (4) $\mathrm{Gr}_{4}(93 \mathrm{~m})$. The base of each Member consists of

Figure 7. Cyclic sequences of the Vendian molasse in the stratotypic section and principal phases of foredeep development, modified after [Sovetov and Blagovidov, 1998].

Symbols: 1-7 - deposits of stream channels and valleys of various types: 1 - braided gravel dominated valley, 2 - braided sand dominated valley, 3 - meandering sand dominated valley, 4 - ephemeral streams, 5 - anastomosing sand dominated stream, 6 - deltaic channels, 7 - low-sinuosity stream with bars, 8 - extra-channel (floodplain) deposits; 9-13- deposits of shelf systems: 9 - sand bars of upper and middle parts of the foreshore zone and beach (the upper shallow marine assemblage), 10 - same (the middle shallow marine assemblage), 11 - sand and silt-sand dominated storm-reworked and hemipelagic interbar portions of foreshore and distal zones (the middle shallow marine assemblage), 12 - stormreworked sand and interbar laminites of various parts of the foreshore zone (the upper shallow marine assemblage), 13 - bedded stromatolite and granular dolomites of the supratidal beach zone, 14 - various sequences of Riphean basement of the southern Yenisei-Cis-Sayan foredeep. 
several major massive beds of cross-laminated sandstones with siltstone intraclasts, and its bulk consists of alternating massive non-laminated silty unsorted sandstones and crosslaminated sandstones and siltstones with a variety of lowvelocity stream marks indicative of levee and floodplain environments.

The Veselaya Formation, composed of redbed clastic deposits, is distinguished by its lack of siltstone beds of any considerable thickness, while retaining only small sandstone intraclasts and abundant siltstone intraclasts in sandstones. The structural uniformity of closely spaced massive layers of thickly cross-laminated loose porous coarse- to fine-grained sandstones and the absence of marker surfaces obstruct a more refined subdivision. Nonetheless, based on stratigraphic intervals with more closely spaced siltstone packages, the Veselaya Formation has been subdivided into four Members with upward-fining material and upward-thinning layers: $\mathrm{Vs}_{1}(97 \mathrm{~m}), \mathrm{Vs}_{2}(59 \mathrm{~m}), \mathrm{Vs}_{3}(55 \mathrm{~m})$, and $\mathrm{Vs}_{4}(49 \mathrm{~m})$. The Greben and Veselaya Formations are exposed on both flanks of the Shalygino anticline. The establishment of new Formations is validated by the change in sedimentary systems, which, on a regional scale, is expressed in broad occurrence of their stratigraphic correlatives in the northern CisSayan zone and on the south and northeast of the Yenisei Ridge. These Formations also differ in terms of petrographic composition of sandstones [Sovetov et al., 1975].

The Redkolesnaya Formation (Rl, $295 \mathrm{~m}$ ) makes up the upper part of the Taseyeva Group, its complete stratigraphic range being exposed on the northeastern flank of the Shalygino anticline. It is composed of orange-, brick-, and cherryred sandstones of variable grain size and with pebbles or lenses of conglomerates with fragments of durable materialquartz and quartzite. The Redkolesnaya Formation is subdivided into two Subformations: Lower $\left(\mathrm{Rl}_{1}, 180 \mathrm{~m}\right)$ and $\mathrm{Up}-$ per $\left(\mathrm{Rl}_{2}, 115 \mathrm{~m}\right)$. The boundary between the Subformations runs at the base of a gravelly sandstone member with gravelstone lenses. The Lower Subformation is subdivided into three Members, each recording a depositional cycle, from bottom to top: (1) $\mathrm{Rl}_{1}^{1}(80 \mathrm{~m}),(2) \mathrm{Rl}_{1}^{2}$ (58 m), (3) $\mathrm{Rl}_{1}^{3}$ (32 m). Lower parts of the members consist of massive thickly crosslaminated and parallel-laminated sandstone with dispersed pebbles and heavy mineral grains, and upper, of platy thinlaminated or vaguely laminated sandstones with gradationally sorted material. The base of the first Member is poorly exposed, a situation where platy thin-bedded deposits usually appear in this outcrop. The Upper Subformation comprises four Members, from bottom upward: (1) $\mathrm{Rl}_{2}^{1}(35 \mathrm{~m})$, (2) $\mathrm{Rl}_{2}^{2}(27 \mathrm{~m}),(3) \mathrm{Rl}_{2}^{3}(28 \mathrm{~m})$, and (4) $\mathrm{Rl}_{2}^{4}(25 \mathrm{~m})$. In the Upper Subformation, platy sandstone varieties (tempestites) are subordinate, whereas packages and members of thinlaminated sandstones and the most coarse-grained massive thickly cross-stratified sandstones, hosting quartz pebbles and lenses of small- to medium-pebble conglomerates, are widespread.

The basis for structural analysis of the Vendian molasse was provided by a detailed sedimentologic description of vertical successions of deposits (lithofacies) in the lithotypic locality on the southeast of the Yenisei Ridge. The lithofacies analysis involved identifying and classifying ca. 2000 layers, in turn grouped into higher rank systems. The largest sedimentary body - the Vendian molasse as a whole - was classed as a 1st rank sedimentary system. The smallest unit (6th to 8th rank) is lithofacies (21 lithofacies for fluvial 21 lithofacies for marine systems). Identification of all the intermediate ranks of sedimentary systems drew on the morphology of bodies, architecture of successions, their frequency distribution in the stratigraphy, size, and origin. The 2nd rank sedimentary systems have a regional extent. This rank covers four sedimentary systems (genetic assemblages): (1) the lower terrestrial (fluvial), (2) the lower (stratigraphically medium) shallow water marine, (3) the upper terrestrial (fluvial), and (4) the upper shallow water marine.

The lower fluvial assemblage is represented by deposits of the Aleshino Formation $(930 \mathrm{~m})$, and it is subdivided into two sub-assemblages, stratigraphically corresponding to Subformations: lower $(580 \mathrm{~m})$ and upper $(350 \mathrm{~m})$. Each subassemblage records a megacycle of terrestrial sedimentation, reflecting a sharp orogenic pulse followed by gradual flattening out of topographic relief. The lower sub-assemblage consists of three fluvial systems, replacing one another through time in the periglacial region and pertaining to (1) a braided gravel-dominated stream, (2) a meandering sand-dominated stream, and (3) ephemeral streams and, possibly, loesses of the distal zone of a fluvial plain. The nomenclature of fluvial systems draws on three features: (1) the predominant grain size of clastic material in the channels, (2) the type of rock assemblages in the channels, and (3) their relationship to extra-channel fluvial plain deposits [Sovetov and Blagovidov, 1998]. Gravelstones and sandstones in the lower sub-assemblage consist chiefly of quartz and, to a lesser extent, lithoclastic material, transported in $\mathrm{W}-\mathrm{NW}$ and $\mathrm{N}$ directions. The earliest gravel-dominated stream carried clastic material from the craton into an outer basin. The upper sub-assemblage of terrestrial deposits is represented by fluvial systems of (1) an anastomosing gravel-dominated stream, (2) ephemeral sand-dominated streams, (3) a meandering sand-gravel dominated stream, (4) a braided sanddominated stream, and (5) a deltaic plain [Sovetov and Blagovidov, 1998]. The direction of transport of clastic quartz and lithoclastic material, in nearly all the systems, was to the N-NW, along the foredeep, being to the SW and SE only in late Aleshino time, in a braided stream.

The lower marine assemblage $(270 \mathrm{~m})$, represented by deposits of the Chistyakovo Formation, is subdivided into three sequences, recording eustatic sea-level oscillations and migration of depositional zones. Within the sequences, we have identified 14 types of sedimentary systems recording depositional environments switching from deltaic plain to coastal zone through to various shelf zones [Blagovidov and Sovetov, 1998]. It is critical that the two upper sequences begin with dramatic sea-level drops, depositional breaks, and drastic inputs of coarse material into the basin. In the lower sequence, a similar role is played by fluvial deposits of incised channels in the upper part of the Aleshino deltaic sedimentary system.

The upper fluvial assemblage $(646 \mathrm{~m})$ is established within the range of the Greben and Veselaya Formations and is subdivided into two sub-assemblages. Recognized are two regionally extensive fluvial systems, corresponding to the two sub-assemblages: (1) an anastomosing sand-dominated 
stream (413 m) - Greben Formation deposits - and (2) a sand-dominated stream with bars $(233 \mathrm{~m})$, represented by deposits of the Veselaya Formation. Stream directions for the anastomosing fluvial system, as measured on numerous sole marks and trough cross-lamination in channels, range through a $120^{\circ}$ sector from NE to NW, the average direction $(n=132)$ being to the north. Measurements on intercept channel deposits show deviations to the E-SE. Based on the totality of data on lithofacies, grain size, stream direction, the proportion of channel to extra-channel deposits, and the geometry of bodies and architecture of the succession, the system is anastomosing in type [Nadon, 1994]. The peculiarity of the Vendian anastomosing fluvial system is the development of a central channel and a network of minor branches, rendering this system similar to a giant debris cone. This association (alluvial system) of a low-sinuosity sand-dominated stream with bars is distinguished primarily by fine clastic components being subordinate. The system is overwhelmingly dominated by lithofacies of channels that were larger and deeper than those of the preceding anastomosing stream, which is due to a cardinal change in the topography of the orogen and its adjacent fluvial plain. The direction of channel thalwegs ranged from $\mathrm{W}-\mathrm{NW}$ to $\mathrm{E}-\mathrm{NE}$, the average direction being northerly. Comparison of various parameters of the fluvial systems of the first and second sub-assemblages shows that, at the level of the Veselaya Formation, the depositional style suffered a dramatic regionalscale change. Multi-channel stream became a deeper, singlechannel stream, directed unimodally to the north.

Shallow marine deposits of the upper part of the molasse make up the Redkolesnaya Formation (295 m). The upper shallow marine assemblage is comprised of a single sedimentary system, composed of groups of deposits of nearshore marine zone. Conglomerates at the base of the assemblage, traceable as a discontinuous member across the Yenisei Ridge and the Cis-Sayan zone, were viewed as making the basal unit of the succession [Anatolyeva, 1972; Khomentovsky et al., 1972; Sovetov, 1977; Zharkov et al., 1974], but, in the foredeeps, stratigraphic break below the upper marine assemblage is missing. In this study, I interpret the conglomerates to record the peak of orogeny and progradation of the terrigenous assemblage onto the Siberian craton in an environment of regionally extensive marine transgression. Composite cyclic sedimentation pattern records a successive advent of four principal environments: (1) back-bar lagoon, (2) beach and upper to middle subzones of the foreshore zone, (3) lower subzone of the foreshore zone, and (4) transition from beach to inner shelf. When paired, these packages make up shoreline migration cycles. The lower half of the assemblage is dominated by a transgressive trend, whereas major cyclic sequences of the Upper Redkolesnaya Subformation, structurally regressive, suggest a general shoreline retreat and progradation of the nearshore assemblage. Progradation took place by lateral accretion of the beach due to successive amalgamation of beach ridges to form strand plain. Taken together, these data suggest orogenic pulses controlling the input of sand material to the delta and its subsequent dispersal along the shoreline and removal into the shelf interior. In the lower part of the assemblage, the migration direction of bars ranged from NW (landward) to E-NE (seaward). At first, in the upper part of the assemblage, currents and bar migration were directed persistently to the east, seaward, whereas in the upper, most coarse-grained part of the assemblage, westward and eastward directions, as well as NW-NE to SE directions along the shoreline, are equally important.

In the northern Yenisei foredeep, the lower marine assemblage of the Late Vendian molasse on the west of the Yenisei Ridge (Stolbovsky Formation), resting with stratigraphic unconformity on Riphean strata, consists of three depositional sequences, indicative of sedimentary systems evolving in succession from sea-level lowstand to marine transgression through to sea-level highstand [Sovetov et al., 2000]. Deposition took place on a coastal plain in a carbonate phytolith system, incised by deposits of fluvial debris cones with clastic material being supplied to the basin from the west, down the uplifted blocks of the Riphean accretionary assemblage. Fluvial debris cones predated the first regional-scale marine transgression, and they are composed of outwash plain glaciofluvial deposits. These assemblages are ponded in local depressions in the foredeeps and consist of material derived from the craton and an external source, uplifted after ice cap melting. The bulk of the Chapa (Nemchansky) redbed molasse, with its three units, in the two northern foredeeps of the Yenisei Ridge, is composed of upward-coarsening fluvial systems. In the southern YeniseiCis-Sayan foredeep, their stratigraphic correlatives are fluvial systems of the Greben, Veselaya, Aisa, and, partly, Uda Formations, as well as the clastic nearshore marine assemblage of the Redkolesnaya, Ust-Tagul, and Nurtei (Shaman) Formations. The development of the Cis-Sayan depression and the southern Yenisei-Cis-Sayan foredeep strongly resembles the basins of the Yenisei Ridge. Molasse deposition began after a stratigraphic break and considerable denudation of the upper part of the successions that filled in the Late Riphean Karagas basin. Denudation was due largely to bedrock exaration by glaciers and to glaciofluvial erosion. The first marine transgression (Ozerki stage) inundated denudation-related depressions, the second (Bolshaya Aisa stage) reworked a great mass of craton-derived clastic material in deltaic and shelf environments, and the third (Peshcherny stage) covered the entire southern part of the would-be foredeep and gave rise to shallow water carbonate systems. Judging from the direction of the facies trend, marine transgressions advanced onto the craton from an outer western basin and a remnant southern basin between the craton and accreted terranes.

The upper terrestrial assemblage (Uda-Aisa) of the CisSayan depression is comprised of at least two fluvial system, directed onto the craton and northwestward along the foredeep, that are sedimentologic and genetic counterparts to those in the Yenisei Ridge basins. The upper marine assemblage locally incorporates a wedge of the Ust-Tagul fluvial conglomerates.

Overall, the architecture of the Vendian molasse persists into the Baikal foredeep, where, under the influence of the northern Baikal remnant marginal sea, marine and transitional environments became widespread. The lower marine assemblage (Uluntui Formation) rests with a stratigraphic break at the base on weathering mantle on top of the Late 


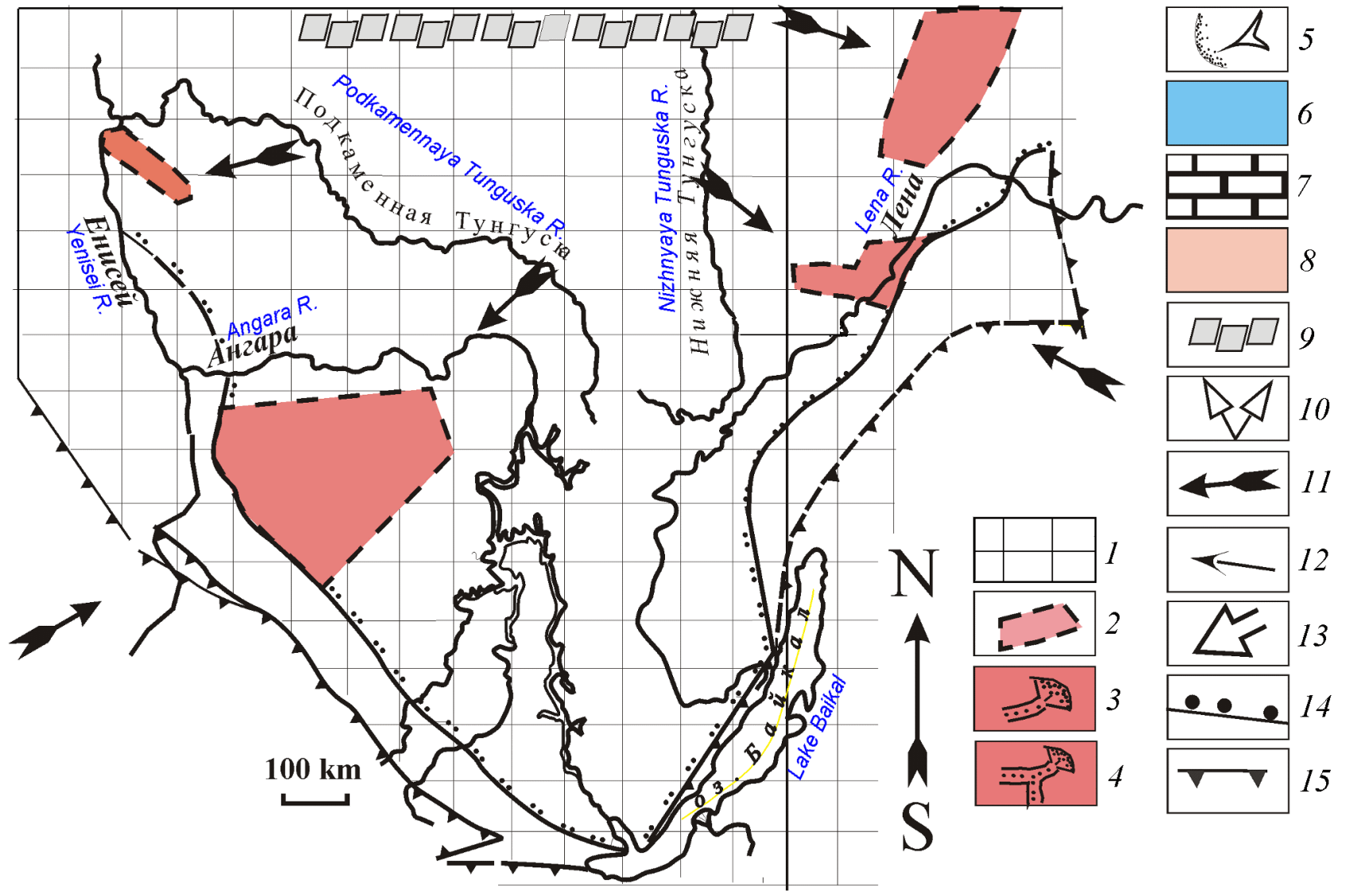

Figure 8. Paleogeographic scheme showing the foreland basin of the southwestern Siberian craton during the accretionary phase of its evolution (Early Vendian, early Aleshino-Betenchinsky time). Initiation of grabens, precursors to foredeeps; sea-level lowstand and ice cap initiation.

Symbols to Figures 8-12: 1 - basement (socle) of the Siberian craton and of continental terranes accreted onto it in the Vendian; 2 - outline of nascent molasse grabens; 3 - braided fluvial plain; 4 - anastomosing fluvial plain; 5 - glaciofluvial debris cones; 6 - shallow marine (shelf) sedimentary systems; 7 - shallow marine carbonate systems of deglaciation-driven marine transgressions; 8 - coastal and strand plain composed of sand deltas; 9 - inferred ice cap boundary; 10 - stream directions, as inferred from sole marks, plunge of troughs, and cross-stratified series in channel deposits of fluvial molasse assemblages; 11 - directions of clastic fluxes (principal); 12 - same, subsidiary; 13 - marine transgression directions; 14 - boundary of sedimentary cover of the Siberian craton; 15 - cratonic boundary.

Riphean Goloustensky Formation carbonate rocks and consists of inner shelf deposits with microphytolith bar systems. The upper fluvial-deltaic assemblage comprises two sedimentary systems: one dominated by deltaic platform and prodeltaic deposits with subordinate channel lithofacies (Kachergat Formation) and the other, fluvial (Ushakovka Formation). Marine regression and accumulation of deltaic sediments began with prodeltaic siltstone deposition, followed by incision of channels and rapid progradation of channel sediments onto the craton and northeastward along the foredeep. The powerful pre-Ushakovka tectonic pulse, synchronous to a similar event in the Yenisei zone, gave rise to new orogens and resulted in alluvium becoming widespread in the Baikal foredeep. The Upper marine assemblage (Kurtun Formation), produced by regionally extensive marine transgression advancing from cratonic interior and redepo- sition of fluvial sands, correlates to a similar assemblage in neighboring sections of the Cis-Sayan depression.

The basal fluvial assemblage in the Patom foredeep rests on basement rocks and fills in local graben depressions (Talakan Formation, up to $400 \mathrm{~m}$ ). Local marine ingression into grabens is best expressed in the nearshore marine system on the north of the foredeep, in the Nyuya-Dzherba basin (Khoronokh Formation), giving way southward to a fluvial system. The first event of massive progradation of alluvium onto the craton is represented by Talakh Formation strata and their stratigraphic counterparts (the lower coarse-grained member of the Parshino Group). Incision of stream valleys and broad occurrence of fluvial deposits in the upper fluvial assemblage are related to the same tectonic episode at the western and southern boundaries of the craton, recording the beginning of formation of the regionally 
extensive cover of the Siberian craton. The lower terrestrial assemblage gives way, in the Patom foredeep, to the lower marine assemblage (fine clastics (the upper half of the Lower Parshino Subformation) on the south and carbonate-sulfate rocks (Besyuryakh Formation) on the north). Sedimentary systems replacing one another laterally indicate that marine transgression was directed from the northeast and east, from the marginal sea of the Yudoma-Maya basin. The upper fluvial assemblage in the Patom foredeep is stratigraphically constrained to within the range of the Khamakinsky Formation, deposited on earlier assemblages with stratigraphic unconformity [Lebedev and Chernova, 1996]. The marine basin occupied most part of the foredeep and rapidly displaced terrestrial depositional environments. Compared to the upper terrestrial assemblage of the Yenisei zone, its counterpart in the Patom foredeep is narrower and occupies a negligible area. The marine assemblage-fine clastics (the upper part of the Parshino Formation, or the Arylakh Formation [Lebedev and Chernova, 1996]) on the south of the foredeep and clayey carbonate deposits (Ynakh Formation) on the north-has no sedimentologic correlatives at the southwestern margin of the foreland basin, giving way here to the upper terrestrial assemblage. Within these assemblages of various origins, there passes a continuous boundary, whose implications to correlation and geodynamics remain everywhere the same, and which separates, on the southwest, fluvial systems of anastomosing and braided types and is marked by orogeny and rejuvenation of fluvial network. This boundary runs inside the Nemchansky, Moshakovsky, and Aisa Formations and between the Kachergat and Ushakovka Formations, and, in the Patom foredeep, it separates two marine systems - the lower (Ynakh), more abundant in carbonates, and the upper (Kharystan), terrigenous-carbonate, overlying the lower with erosion and the "Kharystan" sandstone bed at the base. The upper marine assemblage in the Patom foredeep (Byuksky Formation) originates from a regionally extensive marine transgression, directed from the northern and eastern passive margins of the Siberian craton, and consists almost entirely of carbonate deposits. Two members of nearshore marine sandstones - Botuoba in the lower part and the Upper Tirsky in the upper part of the Byuksky and Tirsky Formations - originate from alluvium, preserved during large-scale marine transgression only in the Yenisei zone of foredeeps, being redeposited in a nearshore environment.

\section{Paleogeography and Stages of Formation of the Foreland Basin of the Siberian Cratonic Margin in the Vendian}

In the Vendian, over most part of the Siberian craton sedimentation was predated by a depositional break and intensive erosion of the deposits of Late Riphean aulacogens and crystalline basement rocks. On the Yenisei Ridge, the Vendian Chapa (Nemchansky) and Taseyeva Groups rest on sedimentary assemblages of the Teya-Chapa, Vorogovsky, and Oslyansky aulacogens with a low-angle unconformity, lapping over them onto basin slopes composed of older Riphean assemblages and basement blocks [Postelnikov, 1973; Semikhatov, 1962; Sovetov, 1993; Sovetov et al., 2000]. In this respect, the structural setting of the Vendian molasse with a glacial horizon at the base on the Siberian craton is identical to that on the Eastern European craton.

In the Vendian, the Siberian craton passed three evolutionary phases: (1) initial accretionary, (2) glacial (precollisional), and (3) collisional. The onset of sedimentation dates the glacial phase to the middle level of the Laplandian glacial horizon [Chumakov, 1978, 1985]. The most depressed portions of the foredeep, beneath the regionally extensive "lower marine assemblage" and its closely associated glacial and glaciofluvial system, retain basal molasse horizons, composed of the lower fluvial assemblage (the Lower Aleshino Subformation) and its lateral correlatives (the Betenchinsky and Talakan Formations) (Figure 8). The lower fluvial assemblage is widespread in local marginal graben basins (Taseyeva, Peledui) and is related to the initial phase of continental accretion and, possibly, to the nascent ice cap. Clastic material was transported from the craton, to be redeposited along the initial foredeep and on the passive margin of the remnant flysch basin.

During the glacial phase, three sea-level rises, which are recorded in three regionally extensive sequences, took place. The lower (early Marnya) sequence bears palpable traces of melting of the Siberian ice cap (Figure 9), the middle (late Marnya) and upper (early Uda) sequences having apparently been controlled by the two subsequent cycles of growth and waning of ice caps on numerous continents and microcontinents. The three marine transgressions advanced from the northwest, west, southwest, and southeast, from marginal basins. Precise stratigraphic and sedimentologic correlatives of the "lower marine assemblage" within the Yenisei Ridge (the Chistyakovo and Podyemsky Formations) suggest that nearshore sedimentation was influenced by fluvial systems that advanced from the west, south, and northeast. In the Sayan and Baikal foredeeps, fluvial terrigenous material was supplied from cratonic interior - i.e., in a direction opposite to that in which shallow marine carbonate system pinch out.

The collisional phase was discussed on the basis of petrologic data in [Sovetov, 1977; Sovetov et al., 1975]. In this paper, the reconstructions of the foreland basin draw on sedimentologic data for the Vendian molasse deposits [Blagovidov and Sovetov, 1998; Sovetov, 2001a; Sovetov and Blagovidov, 1998]. Marine regression ensued after a strong tectonic pulse that gave rise to a continuous belt of orogens and initiated the formation of the "upper terrestrial assemblage" and massive progradation of fluvial systems onto the craton. Late Vendian progradation of terrestrial environments has been documented by the appearance of thick fluvial valley assemblages at the base of the Taezhninsky, Greben (Moshakovsky), Ikeisky, and Kachergat Formations and of productive sandstone members (Markovo, Upper Chona 1, Yarakta, Khamakinsky, Ulakhan, Vanavara 1, and Vanavara 2) of the Upper Nepa Subformation in the cratonic interior. In the basins of the Yenisei zone, there formed fluvial plains, chiefly with anastomosing fluvial systems, bounded on the cratonic side by deltas and a shallow marine basin. From that time on, all the marine transgres- 


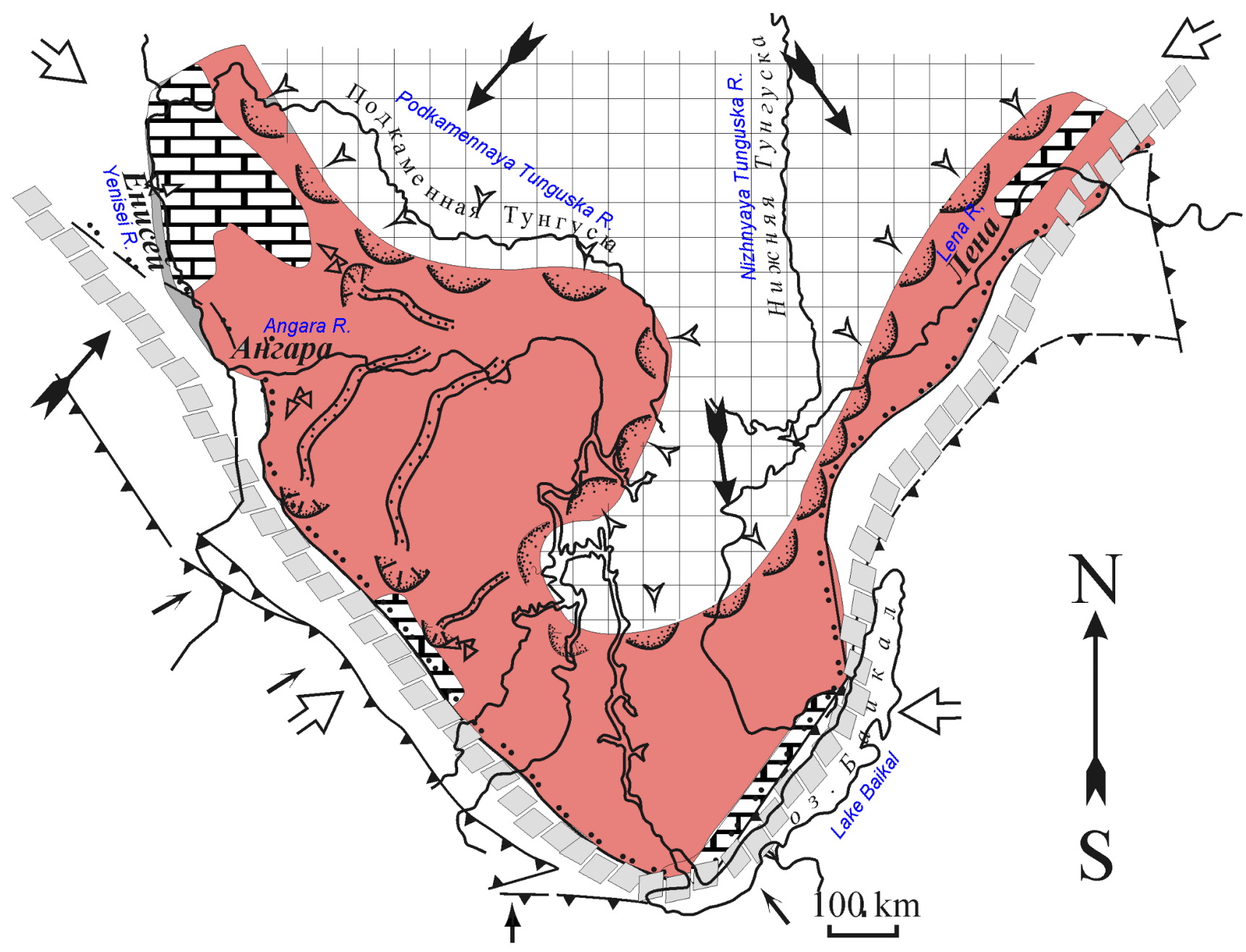

Figure 9. Paleogeographic scheme showing the foreland basin of the southwestern Siberian craton during the glacial phase of its evolution (Early Vendian, late Aleshino to early Marnya through to early Nepa time). Formation of a periglacial plain due to isostatic uplift of the cratonic interior. Shown is the ice cap edge at the peak of glaciation and position of carbonate systems during deglaciation stages.

sions advanced from the north and northeast, from the direction of the passive margins of the Siberian craton (Figure 10).

The late Aisa orogenic pulse at the southwestern and southeastern margins of the craton was manifested in the foredeeps by the progradation of coarse clastic deposits and braided fluvial systems (the Upper Taezhninsky (Middle Nemchansky) and Upper Aisa Subformations, Veselaya, Khuzhir, and Ushakovka Formations) and in the cratonic interior, by the progradation of their correlative sandstone members (Bokhan and Botuoba 1) (Figure 11).

The Ust-Tagul orogenic pulse, which terminates the collisional phase, is recorded by the advance of coarse clastic fluvial members, including conglomerates of the Uglovsky, Redkolesnaya, Ust-Tagul, Nurtei, and Shaman Formations and their correlative marine sandstones of the Upper Tirsky and Botuoba 2 Members. The short tectonic pulse was nearly synchronous to a change in geodynamic regime, a regionally extensive marine transgression, and, ultimately, to the foreland basin being replaced by a saliferous carbonate basin. At the terminal stage, there formed a vast coastal sand plain (strand plain) (Figure 12), represented by the regionally extensive Yenisei-Cis-Sayan petrographic horizon and the nearshore marine sandstone-dominated Parfenovo Member [Sovetov, 1977].

\section{Conclusions}

(1) The Vendian foreland basin of the Siberian craton took shape in the foredeeps and associated forebulges, making up parallel paleotectonic belts conformable to the southwestern margin of the craton. The lower terrestrial molasse assemblage, filling in basins and slopes of uplifts, was formed by sediment supplied from external and internal sources and represented by mature quartz and lithoclastic-quartz mate- 


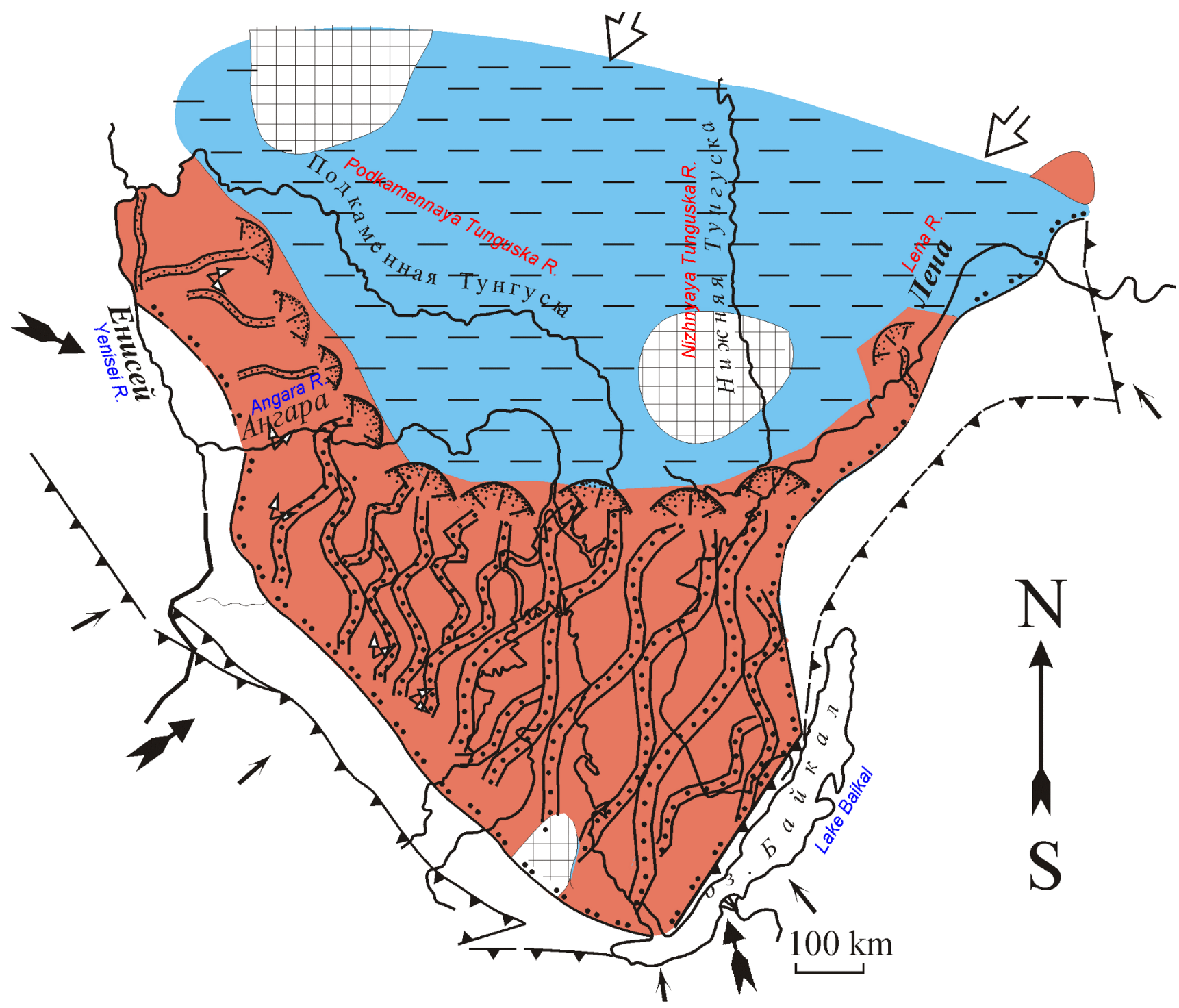

Figure 10. Paleogeographic scheme showing the foreland basin of the southwestern Siberian craton during the early stage of the collisional phase of its evolution (Late Vendian, early Moshakovsky to early Aisa time). Formation of an anastomosing fluvial plain.

rial. The upper terrestrial molasse assemblage was formed by clastics supplied from active external orogens and redeposited from terrigenous and silicite rocks of the Riphean passive margin of the craton. The Sayan zone exhibits direct evidence for a Vendian collisional event-remnant turbidite basins with olistostrome and debrite lithofacies, coeval to overthrusting and tectonic melange.

(2) Three phases in the foreland basin formation are established: (i) initial accretionary, (ii) glacial, and (iii) collisional. Phase one involved the formation of graben basins and two sources of clastic material - intracratonic and external. Based on sedimentologic data (composition of material and flow direction of stream systems, redeposition of eolian sand material into diamictites), the onset of glaciation was related to tectonic accretion. During Phase two, a continental ice sheet was formed, and deposition was controlled by its cyclic growth and waning, with a "centripetal" orientation of sedimentary systems. During the third, collisional phase, a continuous belt of extra-cratonic orogens and the bulk of the upper terrestrial and marine molasse assemblages were formed. The changes in sedimentary systems record three principal collisional stages - Uda, Late Aisa, and Ust-Tagul.

(3) It is for the first time that glacial deposits on the Siberian craton, at the base of the molasse (Oselkovaya Group in the Cis-Sayan basin), and their correlatives in the cratonic interior, are established. The transport directions of material by glaciers and glaciofluvial, eolian, and fluvial processes prove that glaciation was of continental nature. The association of glacial diamictites with cap dolomites and the abundant Metazoa mollusk assemblage appearing after the first (Ozerki) marine transgression constrain the Siberian glaciation to the Early Vendian and imply its likely corre- 


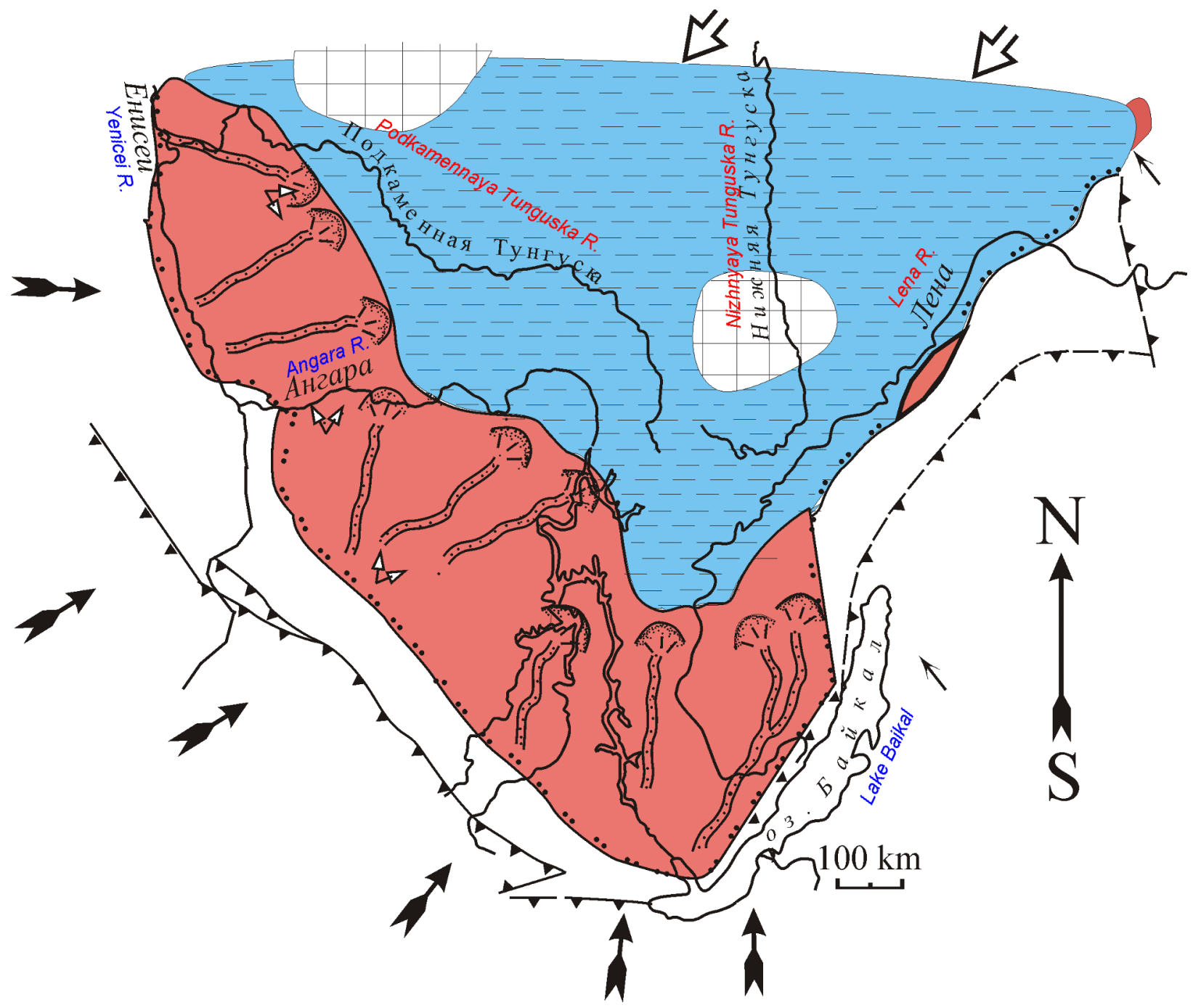

Figure 11. Paleogeographic scheme showing the foreland basin of the southwestern Siberian craton during the late stage of the collisional phase of its evolution (Late Vendian, late Moshakovsky to late Aisa time). Formation of a braided fluvial plain.

lation to the Upper Subhorizon of the Laplandian glacial horizon [Burzin and Kuzmenko, 2001; Chumakov, 1985]. In view of this correlation, the collisional stage reflects the Late Vendian history of the foreland basin.

(4) Overall, the formative scenario of the Vendian foreland basin of the Siberian cratonic margin resembles that for the Vendian sedimentary cover of the Eastern European craton [Aksenov, 1985; Burzin, 1996; Sokolov, 1997]. At the Riphean/Vendian boundary, both cratons were situated in the same climatic zone, and in the Early Vendian they were submerged by ice load, to experience, in the Early to Middle Vendian, three major marine transgressions related to eustatic changes in the ocean, a collision in the Late Vendian, and the formation of terrestrial and near-terrestrial basins. Geochemical and geochronologic data suggest that, at the southwestern boundary of the Siberian craton, the collisional phase is correlative to two tectono-thermal events: in the Early Vendian, ca. $617 \mathrm{Ma}$, the formation of Nyu- rundikan enderbite assemblage on the North Baikal Highland [Amelin et al., 2000]; before the Vendian or in the Early Vendian, ca. $637 \mathrm{Ma}$, eruption of the calcalkaline volcanic suite in the Cis-Ivinsky zone of the Yenisei Ridge and metamorphism of accreted terranes and autochthonous rocks between 640-615 Ma [Vernikovsky et al., 2001]; in the Late Vendian, ca. 550-555 Ma, metamorphism of Shumikha Massif plagiogneisses and emplacement of Verkhnekansky Massif trondhjemites in Eastern Sayan [Nozhkin et al., 2001; Rumyantsev et al., 2000]. These tectono-thermal events may record the initial phase, during which island arcs and microcontinents accreted onto the Siberian craton, and the final collision. The timing and type of events in the Vendian on the other cratons and microcontinents [Sovetov, 2001b] provide convincing evidence that the same timespan included the Pan-African-Brazilian accretion of southern continents and, possibly, the formation of the continuous supercontinent Paleopangea. 


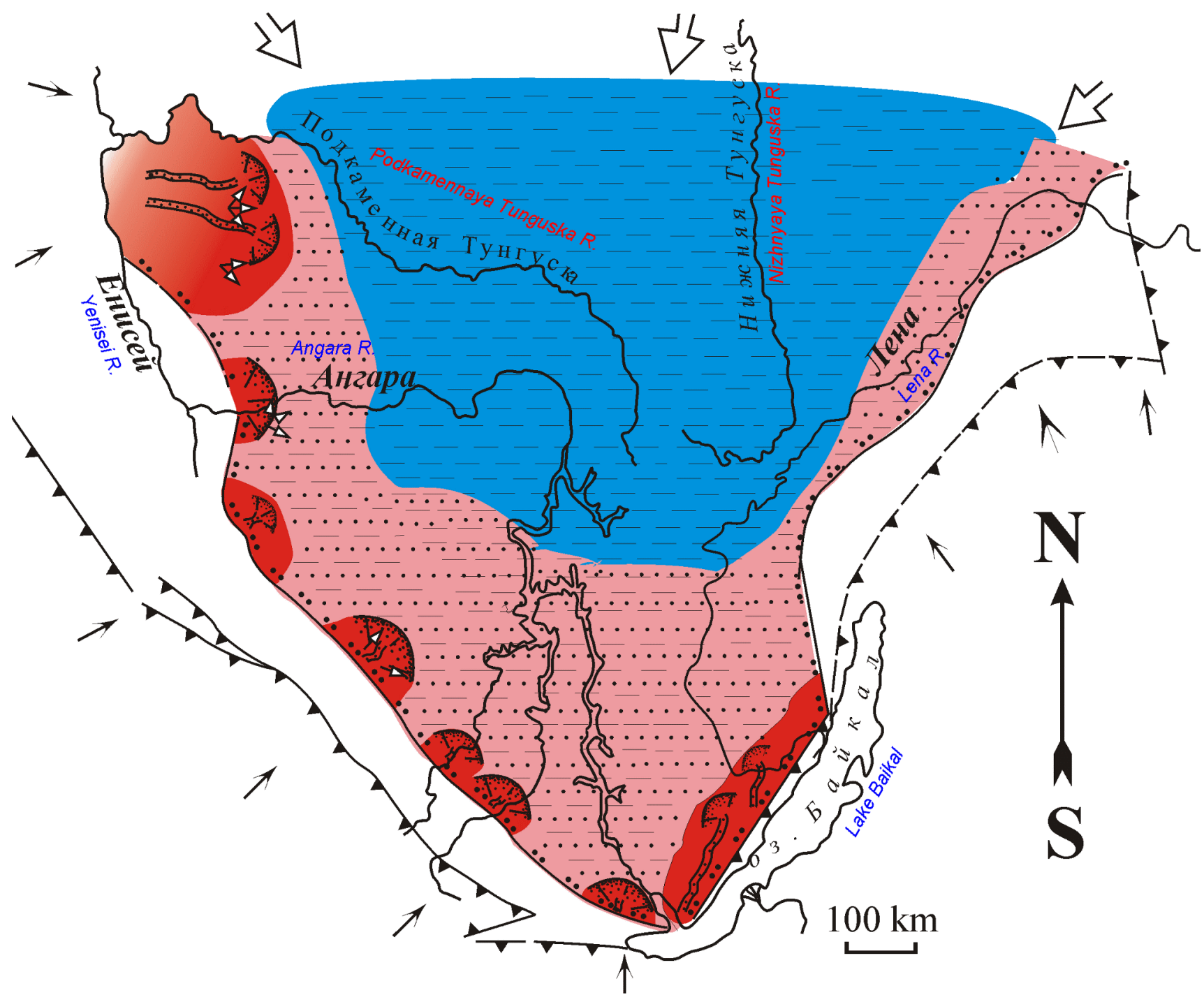

Figure 12. Paleogeographic scheme showing the foreland basin of the southwestern Siberian craton at the final stage of the collisional phase of its evolution (Late Vendian, Redkolesnaya to early Ust-Tagul time). Formation of a coastal (strand) plain.

Acknowledgments. This work was supported by the Russian Foundation for Basic Research, project no. 00-05-65447, and by the Universities of Russia Foundation, project no. ZN-328-98.

\section{References}

Aksenov, E. M., The Vendian of the Eastern European craton, in The Vendian System, A Historical Geologic and Paleontologic Validation, Vol. 2. Stratigraphy and Geologic Processes, pp. 3 34, Nauka, Moscow, 1985.

Akulcheva, Z. A., E. M. Galperova, E. L. Drobkova, L. A. Lysova, T. N. Titorenko, A. A. Treshchetenkova, and Z. Kh. Faizulina, Motskaya deposits and their counterparts in the Irkutsk amphitheater, in Precambrian/Cambrian Transiton Deposits of the Siberian Craton: Biostratigraphy, Paleontology, and Formation Conditions, pp. 65-139, Nauka, Novosibirsk, 1981.
Allen, P. A., P. Homewood, and G. D. Williams, Foreland basins: an introduction, Spec. Publ. Int. Ass. Sediment., 8, 3-12, 1986.

Amelin, Yu. V., E. Yu. Rytsk, R. Sh. Krymsky, L. A. Neimark, and S. G. Skublov, Vendian age of enderbites of the granulite assemblage of the Baikal-Muya ophiolite belt, northern Cisbaikalia: $\mathrm{U}-\mathrm{Pb}$ and $\mathrm{Sm}-\mathrm{Nd}$ isotope evidence (in Russian), Dokl. Ross. Akad. Nauk, 371, (5), 652-654, 2000.

Anatolyeva, A. I., Pre-Mesozoic Redbed Deposits, Trudy Inst. Geol. Geokhim. Sibir. Otd. Akad. Nauk SSSR, issue 190, 323 pp., Nauka, Novosibirsk, 1972.

Beaumont, C., Foreland basins, Geophys. J. Royal Astron. Soc., 65, 291-329, 1981.

Blagovidov, V. V., and J. K. Sovetov, Architecture of the shallow marine sequence in the foreland basin on the southwest of the Siberian craton (Early Vendian, Yenisei Ridge), in Regularities of Architecture of Sedimentary Sequences (abstract), 183-188, UGGGA, Yekaterinburg, 1998.

Bragin, S. S., On the relationships between the Karagas and Oselkovaya Groups, Sic-Sayan region, in Stratigraphy of the Late 
Precambrian and Early Paleozoic of Siberia, pp. 133-147, Inst. Geol. Geophys. Siber. Divis. USSR Acad. Sci., Novosibirsk, 1984.

Bragin, S. S., Oselkovaya Group of the Late Precambrian of the Sic- Sayan region: Subdivision and correlation, in Stratigraphy of the Late Precambrian and Early Paleozoic of Siberia, pp. 4457, Inst. Geol. Geophys. Siber. Divis. USSR Acad. Sci., Novosibirsk, 1985.

Burzin, M. B., Biostratigraphy of the Upper Vendian of the Russian Plate, in Paleogeography of the Vendian and Early Paleozoic (PVEP-96), pp. 29-32, Inst. Geol. Geochem. Ural. Divis. Russ. Acad. Sci., Yekaterinburg, 1996.

Burzin, M. B., and Yu. T. Kuzmenko, The succession of global events in the Vendian, in Supercontinents in the Geologic Development of the Precambrian, paper presented at June 4-6, 2001, meeting in Irkutsk, 44-47, Inst. Earth Crust, Siber. Division, Russ. Acad. Sci., Irkutsk, 2001.

Chechel, E., Cyclomedusa finds from Ostrovnaya Formation deposits, Yenisei Ridge (in Russian), Geol. Geofiz., 11, 118-120, 1976.

Chumakov, N. M., Precambrian Tillites and Tilloids, 201 pp., Nauka, Moscow, 1978.

Chumakov, N. M., The Laplandian glacial horizon and its correlatives, in The Vendian System, A Historical Geologic and Paleontologic Validation, Vol. 2. Stratigraphy and Geologic Processes, pp. 167-198, Nauka, Moscow, 1985.

Dewey, J. F., and J. M. Bird, Plate tectonics and geosynclines, Tectonophysics, 10, 625-638, 1970.

Dickinson, W. R., Plate tectonics and sedimentation, in Tectonics and Sedimentation, edited by W. R. Dickinson, Spec. Publ. Soc. Paleont. Miner., 22, 1-27, Tulsa, 1974.

Dickinson, W. R., Provenance and sediment dispersal in relation to paleotectonics and paleogeography of sedimentary basins, in New Perspectives in Basin Analysis, edited by K. L. Kleinspehn and C. Paola, pp. 3-25, Springer-Verlag, Berlin-New YorkHeidelberg, 1988.

Einsele, G., Sedimentary basins, Evolution, facies, and sediment budget, Springer-Verlag, Berlin Heidelberg, 628 pp., 1992.

Eyles, N., and C. H. Eyles, Glacial depositional systems, in Facies Models Response to Sea Level Change, edited by R. G. Walker and N. P. James, pp. 73-100, Geol. Assoc. Canada, Love Printing Service Ltd., Stittsville, Ontario, 1992.

Grigoriev, V., and M. Semikhatov, Stratigraphy and geologic history of the Lower Cambrian of the northern Yenisei Ridge (in Russian), Izv. Akad. Nauk SSSR, Ser. Geol., 1, 30-45, 1961.

Homewood, P., P. A. Allen, and G. D. Williams, Dynamics of the molasse basin of western Switzerland, Spec. Publs. Int. Ass. Sediment., 8, 199-217, 1986.

Ingersoll, R. V., and C. J. Busby, Tectonics of sedimentary basins, in Tectonics of Sedimentary Basins, edited by C. J. Busby and R. V. Ingersoll, pp. 1-51, Blakwell Science, Oxford, U.K., 1995.

Johnson, D. D., and C. Beaumont, Preliminary results from a platform kinematic model of orogen evolution, surface processes and the development of clastic foreland basin stratigraphy, in Stratigraphic Evolution of Foreland Basins, edited by S. L. Dorobek and G. M. Ross, SEPM Spec. Publ., 52, 3-24, 1995.

Jordan, T. E., Thrust loads and foreland basin evolution, Cretaceous Western United States, AAPG., 65, 2506-2520, 1981.

Jordan, T. E., P. B. Fleming, and J. A. Beer, Dating thrust-fault activity by use of foreland-basin strata, in New Perspectives in Basin Analysis, pp. 307-330, New York-Berlin-Heidelberg, Springer-Verlag, 1988.

Khain, V., M. Volobuev, I. Vorobyev, et al., Principal phases of tectonic evolution of the Yenisei Ridge in the Precambrian and Early Paleozoic (in Russian), Vest. Mosk. Gos. Univ., 5, 7079, 1967.

Khomentovsky, A., Structure and tectonics of the southwestern Siberian craton (in Russian), Byull. Mosk. O-va Ispyt. Prirody, Ser. Geol., (5-6), 115-137, 1945.

Khomentovsky, V., Structural and facies zones of the Lower Cambrian and Riphean at the southwestern margin of the Siberian craton (in Russian), Izv. Akad. Nauk SSSR, Ser. Geol., 12, 42-49, 1959.

Khomentovsky, V. V., The Vendian of the Siberian craton, in The Vendian System, A Historical Geographic and Paleontologic Validation, Vol. 2, Stratigraphy and Geologic Processes, pp. 63161, Nauka, Moscow, 1985.

Khomentovsky, V. V., The Baikalian: A pivotal phase in the evolution of Siberia, in Geology and Geochronology of the Precambrian of the Siberian Craton and Its Surrounding Areas (A Collection of Scientific Papers), pp. 222-237, Nauka, Leningrad, 1990.

Khomentovsky, V. V., and L. N. Repina, The Lower Cambrian of the Stratotypic Section in Siberia, 199 pp., Nauka, Moscow, 1965.

Khomentovsky, V. V., et al., Reference Sections of Upper Precambrian and Lower Cambrian Deposits of the Siberian Craton, 356 pp., Nauka, Moscow, 1972.

Khomentovsky, V. V., V. Yu. Shenfil, A. S. Gibsher, M. S. Yakshin, E. P. Butakov, V. G. Pyatiletov, and L. F. Turova, Geologic Structure of the Mana Basin and its Position in the Sayan-Altai "Baikalides", 223 pp., Nauka, Novosibirsk, 1978.

Krasilnikov, B., On Precambrian marginal basins of Siberia (in Russian), Geol. Geofiz., 5, 17-34, 1963.

Lebedev, M., and L. Chernova, Facies models for Vendian terrigenous deposits on the northeast of the Nepa-Botuoba anteclise, Siberian craton (in Russian), Geol. Geofiz., 37, (10), 51-64, 1996.

Lermontova, E. V., Lower Cambrian Trilobites and Brachiopods of Siberia, 222 pp., Gosgeoltekhizdat, Moscow, 1951.

Miall, A. D., Collision-related foreland basins, in Tectonics of Sedimentary Basins, edited by C. J. Busby and R. V. Ingersoll, pp. 393-425, Blakwell Science, Oxford, U.K., 1995.

Mitrofanov, G. L., and N. N. Mitrofanov, Geodynamic regimes and phases of formation of continental crust in western Transbaikalia, in Supercontinents in the Geologic Development of the Precambrian, paper presented at June 4-6, 2001, meeting in Irkutsk, 160-162, Inst. Earth Crust, Siber. Division, Russ. Acad. Sci., Irkutsk, 2001.

Mordovsky, V. T., A contribution to the stratigraphy of ancient sedimentary deposits in the middle reaches of the Uda River (Cis-Sayan Region), Trudy Inst. Nefti Akad. Nauk SSSR, 7, 30-49, 1956.

Mordovsky, V. T., On the boundary of the Cambrian-Precambrian marginal zones of the Irkutsk amphytheater, Proc. Interdepartment, Conf. on Unified Stratigr, Divisions for Siberia, The Precambrian, 117-128, USSR Acad. Sci., Moscow, 1958.

Nadon, G., The genesis and recognition of anastomosed fluvial deposits: data from the St. Mary River Formation, southwestern Alberta, J. Sed. Res., B64, P. 451, 1994.

Nozhkin, A., O. Turkina, E. Bibikova, and V. Ponomarchuk, Composition, architecture, and conditions of formation of metasedimentary-metavolcanic assemblages of the Kansky greenstone belt, northwestern Cis-Sayan region (in Russian), Geol. Geofiz., 42, (7), 1058-1078, 2001.

Obruchev, V. A., A Geological Review of Siberia, GIZ, Moscow, 1927.

Obruchev, V. A., Solving the issue of the Cambrian/Precambrian boundary in Cisbaikalia (in Russian), Izv. O-va Izuchenn. Vost.-Sib. Obl., II (LVIII), 253-261, 1937.

Pavlovsky, E. V., On the Lower Paleozoic of the Cis-Sayan Region, Trudy Vost.-Sib. Filiala Akad. Nauk SSSR, Ser. Geol., 1, 1838, 1954.

Pavlovsky, E. V., New data on the stratigraphy of the Cambrian of Cisbaikalia (in Russian), Dokl. Akad. Nauk SSSR, 14, (1), 18-38, 1937.

Postelnikov, E. S., Baikalian Orogeny: A Case Study in the Yenisei Ridge, 126 pp., Nauka, Moscow, 1973.

Predtechensky, A. A., The ancient uplift of southern Siberia (On the issue of the "ancient sinciput of Asia"), in Materials on Regional Geology, Trudy SNIIGiMS, issue 13, 65-78, Gostoptekhizdat, Novosibirsk, 1960

Resolutions of the All-Union Stratigraphic Conference on the Precambrian, Paleozoic, and Quaternary System of Middle Siberia 
(the Upper Proterozoic and Lower Paleozoic), 215 pp., SNIIGGiMS, Novosibirsk, 1983.

Resolutions of the 4th Stratigraphic Conference on the Refinement of Stratigraphic Schemes for the Vendian and Cambrian of the Interior of the Siberian Craton, 63 pp., MSK, Novosibirsk, 1989.

Rumyantsev, M., O. Turkina, A. Nozhkin, T. Gracheva, and D. Shevchenko, New data on the age of the Shumikha fossil island arc assemblage, Eastern Sayan: Late Riphean-Vendian crust formation at the southwestern margins of the Siberian craton (in Russian), Geol. Geofiz., 41, (12), 1790-1797, 2000.

Schwab, F. L., Evolution of the western continental margin, French-Italian Alps: sandstone mineralogy as an index of plate tectonic setting, J. Geology, 89, 349-358, 1981.

Semikhatov, M. A., The Riphean and Lower Cambrian of the Yenisei Ridge, 242 pp., Trudy Geol. Inst. Akad. Nauk SSSR, issue 68a, Nauka, Moscow, 1962.

Semikhatov, M., and Yu. Trapeznikov, Southwestern boundary of the Siberian craton in the Vendian and Early Precambrian (in Russian), Geotektonika, 4, 36-54, 1965.

Shatsky, N., Principal traits of tectonics of the Siberian craton (in Russian), Byull. Mosk. O-va Ispyt. Prirody, Nov. Ser., Otd. Geol., (3/4), 471-509, 1932.

Shenfil, V. Yu., The Late Precambrian of the Siberian Craton, 184 pp. (Trudy Inst. Geol. Geofiz. Sib. Otd. Akad. Nauk SSSR, issue 790), Nauka, Novosibirsk, 1991.

Shishkin, B., Peculiarities of the architecture of Precambrian and Cambrian deposits of the northeastern Siberian craton (in Russian), Geol. Geofiz., 40, (12), 1795-1807, 1999.

Sokolov, B. S., On paleontologic finds in pre-Usolka deposits of the Irkutsk amphitheater, in Counterparts of the Vendian Assemblage in Siberia, pp. 112-117, Nauka, Moscow, 1975.

Sokolov, B. S., Essays on the Formation of the Vendian, 153 pp., KMK Scientific Press Ltd., Moscow, 1997.

Sovetov, J. K., Upper Precambrian Sandstones of the Southwestern Siberian Craton, 294 pp., Nauka, Novosibirsk, 1977.

Sovetov, J. K., Sedimentologic sequences in Late Riphean aulacogens at south-western margin of the Siberian Platform related to sea-floor spreading, Report 4 of the IGCP Project 283 (abstract), Fourth Intern. Symp. on Geodynam. Evol. of Paleoasian Ocean, 164-167, UIGGM SB RAS, Novosibirsk, 1993.

Sovetov, J. K., Late Precambrian rifting and the Baikalian cycle of geodynamic evolution of the Siberian craton, in The Riphean of Northern Eurasia. Geology and General Stratigraphic Issues, pp. 223-230, Yekaterinburg, Inst. Geol. Geochem., Ural Division, Russ. Acad. Sci., 1997.

Sovetov, J. K., Issues of lithospheric evolution in the Precambrian, paper presented by the Russian participants of the 31st $I G C$ (a school-seminar on board the R/V "Akademik Ioffe", July-August 2000), pp. 276-299, edited by V. I. Goncharov and Yu. V. Mironov, Section Geol., Geochem., Geophys., and Mining, Kordis, Magadan, 2001a.

Sovetov, J. K., Vendian foreland basin of the Siberian cratonic margin: Paleopangean accretionary phases, in Supercontinents in the Geologic Development of the Precambrian, paper presented at June 4-6, 2001, meeting in Irkutsk, 254-258, Inst. Earth Crust, Siber. Division, Russ. Acad. Sci., Irkutsk, 2001b.

Sovetov, J. K., and V. V. Blagovidov, Sedimentologic structure and depositional environments of the Vendian molasse (Yenisei Ridge), Structural regularities of sedimentary sequences, pp. 242-247, paper presented at Ural State Geol. and Mining Academy, Yekaterinburg, 1998.

Sovetov, J. K., and V. V. Blagovidov, Geodynamics of the southwestern Siberian craton in the Vendian, in Geologic Evolution of Proterozoic Cratonic-margin and Paleoceanic Structures of Northern Eurasia, pp. 166-168, paper presented at a conference, TEMA, St. Petersburg, 1999.

Sovetov, J. K., and V. V. Blagovidov, Vendian orogeny-the first stage of Gondwanaland Supercontinent Assembly: evidence of the south-west part of Siberian Platform (abstract), 31st IGC, General Symposia. 9.4. Precambrian Supercontinents, Rio de Janeiro, Brazil, 2000.

Sovetov, J. K., E. P. Akulshina, A. V. Ivanovskaya, and G. M. Pisareva, Architecture, composition, and depositional environments of the Yudoma sedimentary assemblage on the southeastern Yenisei Ridge, in Lithologic and Geochemical Studies of Paleozoic and Precambrian Deposits of Siberia, pp. 82-102, Inst. Geol. Geokhim. Sibir. Otd. Akad. Nauk SSSR, Novosibirsk, 1975.

Sovetov, J. K., V. V. Blagovidov, and L. A. Chigvintseva, The Baikalian cycle of geodynamic development of the southwestern margin of the Siberian craton (project no. 93-05-08795), in The Russian Foundation for Basic Research in the Siberian Region: The Earth's Crust and Mantle, vol. I, 76-77, Inst. Earth Crust, Russ. Acad. Sci., Irkutsk, 1995.

Sovetov, J. K., V. V. Blagovidov, and L. A. Chigvintseva, Stratigraphy and facies of Vendian deposits on the Yenisei Ridge and in adjacent areas of the Siberian craton, in The Geology and Issues of the Search for New Major Oil and Gas Fields in Siberia: Results from the Activities under the Interdepartmental Regional Program "Search" for 1994, part I, 44-48, SNIIGGiMS, Novosibirsk, 1996.

Sovetov, J., V. Blagovidov, V. Luchinina, and A. Romashko, Vendian deposits on the western Yenisei Ridge (in Russian), Dokl. Ross. Akad. Nauk, 372, (2), 222-224, 2000.

Stockmall, G. S., D. J. Cant, and J. S. Bell, Relationship of the stratigraphy of the Western Canada foreland basin to Cordilleran tectonics: insights from geodynamic models, in Foreland Basin and Thrust Belts, edited by R. W. Macqueen and D. A. Leckie, Am. Assoc. Petrol. Geol. Mem., 55, 107-124, 1992.

Tetyaev, M. M., A contribution to the study of the Cambrian section in western Cisbaikalia and Eastern Sayan (in Russian), Vestn. Geol. Kom., 3, (3), 7-14, 1928.

Tsakhnovsky, M. A., Correlation of sections of ancient Paleozoic sequences of the southern margin of the Siberian craton, in Geology and Petroleum Potential of Eastern Siberia, pp. 187248, Gostoptekhizdat, Moscow, 1959.

Vernikovsky, V. A., A. E. Vernikovskaya, and A. I. Chernykh, 5.1.12. The issues of the Precambrian, in Principal Results of Basic Research in First Priority Spheres Conducted by A. A. Trofimuk United Institute of Geology, Geophysics, and Mineralogy in 2000, 69-70, Siber. Division, Russ. Acad. Sci., GEO Branch, Novosibirsk, 2001.

Yanshin, A., The potential for discovering economic deposits of potash salt in Siberia (in Russian), Geol. Geofiz., (10), 3-22, 1962.

Zaitsev, N. S., On tectonics of the southern part of the Siberian craton, in The Issues of Geology of Asia, vol. I, 399-444, USSR Acad. Sci., 1954.

Zamaraev, S. M., Marginal Structures of the Southern Siberian Craton, 246 pp., Nauka, Moscow, 1967.

Zharkov, M. A., et al., The Geology and Potassium Potential of Cambrian Deposits of the Southwestern Siberian Craton, 413 pp., Nauka, Novosibirsk, 1974.

(Received 23 August 2002) 